\title{
CEPAL
}

Review

Executive Secretary of ECLAC

Gert Rosenthal

Deputy Executive Secretary for Economic and Social Development

Andrés Bianchi

Deputy Executive Secretary for Co-operation and Support Services

Robert T. Brown

\section{Director of the Review}

Aníbal Pinto

Technical Secretary

Eugenio Lahera

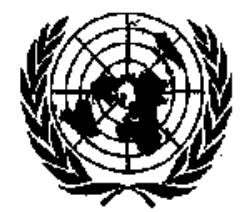

UNITED NATIONS

ECONOMIC COMMISSION FOR LATIN AMERICA AND THE CARIBBEAN

SANTIAGO, CHILE. APRIL 1988 


\section{E P A L}

\section{Review}

Santiago, Chile

Number 34

\section{CONTENTS}

An economic policy for development. Norberto Gonzälez.

An assessment of the structuralist paradigm for Latin American development and the prospects for its renovation. Osvaldo Rosales.

An outline of a neo-structuralist approach. Ricardo Ffrench-Davis.

Neo-liberalism versus neo-structuralism in Latin America. Sergio Bitar.

The challenges facing Latin America in the world today. Guillermo Maldonado Lince.

International primary commodity marketing and Latin America. Mikio Kwwayama.

Urban employment: research and policy in Latin America. Victor E. Tokman.

Small and medium-scale industry in the development of Latin America. Mario Castillo and Claudio Cortellese.

Prebisch's ideas on the world economy. Armando Di Filippo.

Prebisch: a classic and heterodox thinker. Benjamin Hopenhayn.

Raúl Prebisch central banker. Felipe Pazos.

Dependence, interdependence and development. Raúl Prebisch. 
CEPAL REVIEW No. 34

\section{Small and}

medium-scale industry in the development of Latin America

\author{
Mario Castillo and \\ Claudio Cortellese*
}

The option represented by small and medium-scale production has taken on the starus of a vircual paradigm. As such, it is regarded as an effective alternative for coping with unemployment and the shortage of capiral and for maximizing entrepreneurial capabilities and the flexibility of production.

The subject of small and medium-scale industry (SMI) is addressed in this article from a variecy of important and complementary angles. Following a consideration of the conceprual framework for SMI, the authors compare the available evidence relating to Latin America with that pertaining to the industrialized countries. Then, after evaluating three quite distinct regional cases (Brazil, Colombia and Chile), they go on to analyse the successful experiences of Japan and ltaly. In the final section of the article the authors set forth some proposals with respect to the potentials of SMI in the region.

In order to analyse SMI from the standpoint of industrial policy, it is essential to clarify and dispel the formal/informal, traditional/modern dichotomies and, in particular, that said to exist between marginal enterprises and small enterprises operating on the basis of a capicalist approach.

The available evidence at the international level indicates that there is no one standard pattern as regards the development of $\mathrm{SMI}$; rather, a variety of successful experiences substantiate the view thar SMI can function efficiently and make an effective contriburion to development when sociat and inscitutional faccors and elements of economic strategy join together to supposs this oprion.

A selective promotion of SM! may thus play a substantive role in bringing abour a transformaxion of producrion by contribucing to articulation, technological innovation and entrepreneurial development.

"Of the Joint ECLAC/UNIDO lndustry and Technology Division.

The authors wish to express their gratirude for the contributions and comments made by the seaft members of the Joint ECI.AC/UNIDO Division and, in particulat, for the assistance they received from Oscar Altimir and Fernando Fajozylber. They also gratefully acknowledge the information supplied by Mukio Kuwayarna and Peter Palesch.

\section{Introduction}

The controversy surrounding Latin American industry in the 1980s, at a time of deep and prolonged economic crisis, has been strongly influenced by three very significant events. In outline, the first of these is related to the growing frustration felt with the results of the industrialization process during preceding decades; the second has to do with the re-opening of the debate concerning the informal economy, the micro-entrepreneurial phenomenon, public policies and the role of the State apparatus; and the third event is the sweeping technological change which is now takeing place in the advanced countries' systems of production.

The challenge represented by the need to restructure industry in the countries of the region is a broad-ranging one. In the short run, such a reorganization ought to contribute to an expansionary adjustment of the economy which, in the longer term, will in its turn permit a successful articulation with strategies for redirecting development and make it possible for the region to assume an appropriate position in the new international context. This restructuring should not only help to overcome the longstanding disequilibria and asymmetries exhibited in so many different forms in the societies, economies and institurions of the Latin American nations, but should also take into account those external conditions which have taken shape most recently, such as the trends now being observed in the international economy, technological changes, the sharpening of competition and the dwindling flow of external financing.

As the situation in these economies becomes increasingly difficult, the use of small and medium-scale production units is fast becoming an option as one basic component of a new style of industrialization. Given the existence of widespread resource constraints, the explosive growth of the informal economy and of unemployment, the disarticulation of markets, the inflexibility of various aspects of the production structure and the uncertain nature of entrepreneurial leadership, it is understandable that small and medium-scale industry (SMI) hotds an irresistible attraction for a wide circle of analysts, politicians and planners. 
Nonetheless, there is also an enormous gap between the hopes placed in this type of productive organization and the available evidence concerning its real potentials. The current thinking as regards SMI in Latin America is, in our opinion, seriously flawed in that it relies on ambigu. ous conceptual underpinnings and makeshift descriptive and quantitative bases.

The authors' aim in preparing this arricle is to help realign the debate concerning SMI in Latin America, provide new inputs and clear up some common points of confusion. To this end, the article takes an exploratory tack in three directions. These are, firstly, the suggestion of an analytical framework for analysing SMI from the standpoint of industrial policy; secondly, the compilation and analysis of the evidence pertaining to some industrialized countries and to the Latin American region, with particular reference to Brazil, Colombia and Chile; and thirdly, the identification of the most promising prospects for Latin America in the light of both the successful experiences of other countries (Japan and Italy) and the region's unique features and potentials with respect to industrial development.

\section{Contemporary thought concerning SMI}

In the developing countries, the debate concerning small-scale production was re-opened by the publication of an International Labour Organization study on Kenya in the early 1970s (ILO, 1972). ${ }^{1}$ Since then, many more research projects have been done on the role of small and mediumscale enterprises and the impact they have on economic systems. These analyses, whether empirical or theoretical, have concentrated on describing the relationships between small and medium-scale enterprises and the other components of the economic system, the economic characteristics and behaviour of these production units and the obstacles that have held back their development (Schmitz, 1982). Yet the debate is still going on, and it comes as no surprise that many opinions and results appear to contradict one another.

How small and medium-scale enterprises are defined and what possible role they are seen as playing in economic development particularly within the industrial sector, are closely related to the characteristics of the economic system concerned. This article focuses on small and medium-scale industrial enterprises (SMIs), their role in the industrialized countries and the potentials they exhibit in the case of the develop.

'Among the more comprehensive carlier works, see Staley and Morse (1968) and Hoselitz (1959). ing nations. Finally, a paradigmatic definition of small and medium-scale industrial enterprises will be proposed, and it is this definition which will be referred to throughout the article.

With regard to such a definition, it should be noted that the real indicators and variables which are actually used for the classification of firms are not the most appropriate ones for describing the characteristics of a productive organization: There is, inevitably, a gap between the qualitative description and the quantification of business enterprises. The standard of measurement of the variables used to identify real enterprises needs to be simple and easily verifiable, as well as being based on suitable statistical sources. Since in real life it is an accepted fact that it is impossible to measure easily and fully all the identifying characteristics of a firm, analysts have opted for simple variables, such as the number of employees, the value of fixed capital or total sales.

In this article the following classification will be used: i) micro-enterprise: 10 or fewer employees; ii) small enterprise: 10-49 employees; iii) medium-scale enterprise: $50-99$ employees; iv) large enterprise: 100 workers or more. ${ }^{2}$

2On the basis of this classification, many induscries which ane categorized as SMl in developed countries with large markets may 


\section{The role of SMI in industrialized countries}

In the industrialized countries, the articulation existing among the various developmental actors is quite solid and permits a relatively more even blending of the economic performance of each part of the system, as well as ensuring its dynamism. In such economies, SMI is generally an integrated part of the industrial system. ${ }^{3}$ Analyses of the situation in the industrialized countries may be said to have arrived at some degree of consernsus. ${ }^{4}$

The characteristics and potentials of SMI as regards the development of a given economic system have been discussed by various authors." In this article, however, the discussion will be confined to only those major spheres in which SMI has played a significant role: dynamizing the production structure, technological progress and social development.

SMIs are generally more flexible than larger units thanks to the greater ease with which they are able to adjust their use of the factors of production to market conditions. This is particularly true in the case of labour. For a variety of institutional reasons, it is easier for very small units to hire and dismiss personnel. In the remaining cases, the small numbers involved lessen the social reaction and any labour union action in response to dismissals, as well as the risk that bottlenecks may affect staff recruitment. ${ }^{6}$ They are also able to use capital more

be regarded as large enterprises in developing countries. In the United Srates and the Federal Republic of Germany, for example, small and medium-scale enterprises are considered to be thuse employing fewer than 500 people; in Japan, the dividing line drops to 300 employees; in Chile, it is ser at 50 and in Trinidad and Tobago, at only 25 .

'For a scatistical analysis of the impact and ecomomic performance of SMI in some industrialized countries, see the third section of this article.

In the literature concerning SMI in these countries, produc tion units or business establishments are usually classified on the basis of fixed capital and/or the number of empluyees, with the latrer being the must commonly used. Generally speaking production units having between 10 and 500 employees a re caregurized as SMI.

See, inter atis, Hoselitz (1959), Andersun (1982), ECLAC (1988), ECLAC/UNIDO (1986), Schumacher (1973), Berger and Piore (1980), Brusco (1982), Fua (1983), Jkionicoff (1986), Kaneda (1980) and Sechi (1985)

See, for example, Bruscu (1982), Storey (1983), Fua ( 1983) and Berger and Piure (1980). flexibly, since the absolute values involved are such as to permit swift decision-making; furthermore, SMIs can make use of a broader range of production techniques and equipment (i.e., second-hand machinery) since in their case the cost of adaptation is low. These enterprises are also flexible as regards demand; SMIs usually deal in small markers or market segments, and this allows them to meet any variations in demand with appropriare speed.

The technological development of an industrial system consists of innovations (in the processes used, the product concerned or the form of organization) and their dissemination. It is difficult, however, to set out parameters for identifying an individual production unit's contribution to the technological development of an overall system, and this, in the authors view, is one of the abstacles to the achievement of a general agreement as to the correct interpretation of the situation on an empirical basis. Nonetheless, in a number of cases the effective capacity of SMI for technological innovation has been demonstrated.' There does appear to be a consensus, however, as to the fact that SMI does play a highly important role in the dissemination of technology and in new technologies developed on the basis of advances in microelectronics and information sciences: ${ }^{8}$

'In regard to the United Kingdom, see Pavitt, Robson and Townsend (1987). After analysing 4000 "significant" innovarions made in the Unired Kingdum between 1945 and 1983, the authors found that the coefficient of innowarions/employees was above the average in enterprises having fewer than 500 employees and in those having more than 10000 employees. Firms with 100-199 employees had the highest ratio between their proportion of innovations and their share of employment in industry. The results are more significant at a greater level of sectoral disaggregation Cohen, Levin and Mowery (1987) analysed the intensity of research and development in the United States. They concluded that the size of the firm involved in these octivities has no statisti. cally significant effect on $R \& D$ intensity, but that firm size did affect the probability that such activities would be undertaken. In regard w ltaly, see ECLAC (1988), which underscotes the imporrant contribution made by SMI to technological progress, particularly in the field of process-related innovations.

- Regarding the role of SMI in the development of technolugy in the OECD countries, see OECD (1982). Concerning the spread of technolugies to the industrial system and decentralized systems of technological devehoprent, ste Stuhr $(1986)$. A gress deal of lizenture is available on che subject of new technulogies. The topics of the minimum scale of production and technical efficiency have alsa taken on renewed impurta nce; see, inter ulia, Jacubsson and Sigurdson (comps.) ( 1983), Jacobsson (1985), Bhalla and Dilmus (1986). Pérez (1985) and Kaplinsky (1983 and 1985). 
Finally, the role of SMI in social development should be mentioned. The existence of broad networks of small and medium-scale enterprises in Italy and Japan, for example, has strengthened their socioeconomic articulation and social cohesiveness. In Italy, the spread of SMI and the characteristics of this process have permitted a good distribution of industrialization, a low level of concentration in urban areas, the maintenance of some degree of social equilibrium during the process of economic change and a certain measure of institutional stability. ${ }^{9}$ In Japan, the existence of an SMI structure which is particularly well integrated with that of large firms has facilitated a smooth process of economic development and has created the conditions necessary for the social changes needed in the country.

\section{SMI in developing countries}

The potentials and performance of SMI in developing countries have been much analysed; these studies have, however, arrived at what are often contradictory conclusions. ${ }^{10}$

The existing literature highlights the role of SMI in the economic and social spheres. As regards the former, SMI has been characterized as highly labour-intensive, flexible in responding to changes in the market and in technologies, energy-efficient and capable of taking advantage of local abilities and materials. It has also been stated that SMI contributes to a more equitable distribution of income, to a higher rate of saving and reinvestment, and to the integration of the industrial structure. In relation to the social sphere, SMI has been portrayed as making a fundamental contribution to economic democracy by promoting social re-articulation and participation, as fostering entrepreneurship, narrowing the gap between the small cottage industries of the informal economy and large

"Italy's structure of political institutions, which did not cake shape until after the Second World War, has led to a rapid industrial develupment of the country. See LCLAC/UNIDO (1986) and IECLAC (1988).

IOFor an extensive discussion of these subjects and an exhaus. tive bibliography, see Andersin (1982), Little (1987), Liedholm and Mead (1987) and the classic works of Staley and Morse (1965) and of Hoselitz (1959). firms, and constituting an efficient mechanism for the deconcentration of ownership, ${ }^{11}$

Others, however, have taken more cautious positions and have sought to ascertain the actual scope of SMI and the accuracy of the above assertions.

Their doubts concerning the economic performance of SMI are focused on three areas. ${ }^{12}$ The first of these is the production efficiency of SMI. All the studies which have been done agree that the labour productivity of SMI is considerably lower than that of large firms. Nonetheless, some analysts assert that there may be economically efficient technologies or combinations of factors which could raise the productivity of SMI. The debate on this point encompasses the entire and much-discussed subject matter of the influence of prices on the choice of production technologies, the distortion of the prices of factors of production and the elasticity of substitution between capital and labour (Ahluwalia, 1974). The question as to the degree of efficiency of SMI is not without importance, particularly in view of the existing constraints on resources for development (Little, 1987; Anderson, 1982). ${ }^{13}$

The second area of doubt, which is conceptually related to the above, concerns the supposedly greater labour-intensiveness of the technologies used by SMI. Studies have been done which demonstrate, at an aggregate level, that small firms make a greater use of labour in relation to capital. However, other research projects based on disaggregated analyses of the capital/labour ratio or the output ratio have concluded that in many cases SMI makes a greater use of capital per unit of output and per worker. ${ }^{14}$ While we will not go into all the criticisms which have been directed at the theoretical

11See, inter aim, Staley and Morse (1968), Schmitz ( 1982) and JUNOACOMUN, IIDIS and CORDIPLAN (1978)

"In the past few years the World Bank has gained a considerable amount of experience in SMI assistance programmes and in empirical and conceptual research on the rote played by such enterprises. For a quite critical but nonetheless very useful and clearly-presented study on the actual performance of SMI in developing countries, see L.itrle (1987)

'Rates of saving and reinvestment are often higher in SMI, porticularly in medium-scale units (White, 1978, p, 45).

${ }^{4}$ Little (1987, p. 205) asserts that "it is not sufficient to show that SSEs [small-scale enterprises] use more labur and not mure capital per unit of ourput than do larger enterprises. This being sat one could as well employ more workers to do nuthing in latge factories as employ them productively in SSEs". 
assumptions underlying these approaches, ${ }^{15}$ two points should be taken into account: firstly, that the factors of production are not always uniform, and hence in certain cases SMI may use some factors which would otherwise go unused; and, secondly, that microeconomic analyses should also cover all the other elements, in addition to labour and capital, which go into the production of goods, particularly management and organization (White, 1978, p. 39; Stewart, 1977).

Finally, some analysts also question the purportedly dynamic nature of the part played by SMI in technological progress. In this regard, it must be assumed that the evidence drawn from the experiences of industrialized countries holds true, inasmuch as the specialized literature does not contain analyses of specific cases in respect of developing nations. This lack notwithstanding, it is worthwhile noting that SMl may be of importance in the deployment of entrepreneur. ial capabilities and in the dissemination of techniques through the process of "learning by doing". 16

In the authors' opinion, the existence of various characterizations of the actual contribution to development made by SMI is due to the fact that both the economic and social efficiency of SMI, as well as the role it may play, depends upon the socioeconomic context. The uniqueness of each situation and economic and social system militates against the applicability of categorical statements in this respect. ${ }^{17}$

The second problem relates to the great variety of different definitions, both from a conceptual standpoint and in terms of the unit of analysis. The aggregate referred to as "SMI" encompasses a number of categories and concepts which describe intersecting situations and structures which are virtually impossible to dissociate from one another.

'See Ahluwilia (1974) and a number of the other studies presented in the same volume; Stewart and Streeten (1971); Stewatt (1985).

${ }^{16}$ An efforc is now underway to concepeualize the dynamic process of endogen ous technological and industrial develupment, which is referred to in ECIAC studies as the "endogenous technological dynamizacion nucleus". See LCLAC (1985). A brief discussion of these subjects is found in Cortellese (1986).

${ }^{12}$ Nevertheless, ana lyses of past experiences are very useful in formulating hypotheses as to the potentials of SMI, based on the coneext in question.
The basic problem comes down to being one of clearly specifying precisely what type of enterprise is being referred to when discussing the potentials and role of SMI in economic development and when designing policies to promote SMI. ${ }^{18}$

\section{The need for a clear definition of the concepts involved}

In the debate concerning SMI, categories for which no explicit definitions are generally given are used to describe opposing structural situations. Thus, use is made of terms such as informal and formal, traditional and modern, urban and rural, small and large-scale enterprise. $A$ classification based on types of firms necessarily involves a consideration of some qualitative features. These characteristics stem from the way in which the production activity is structured, and the analysis of this structure may be undertaken from the standpoint of either the firm's internal organization or its external relations.

In the latrer case, it is important to consider the firm's market relations, those it establishes with other production units, its relationship to the socioeconomic context, and the strategy involved. ${ }^{19}$

Business enterprises establish relationships with markets in order to sell their products and to buy factors of production and inputs. In most developing countries, the markets for factors of

\footnotetext{
${ }^{10}$ There is a great deal of literatureconcerning the reasuns for policies in support of SMI. For example, see Staky and Morse \{1965\}. Hoselitz (1959), Anderson (1982) and the many World Bank publications on the subject.

The definition of SMI which is used is also functional in terms of industrial policy objectives. Thus, for example, if the $\mathrm{s}$ im is to increase employment in the short run, on impetus should be provided for micro-enterprises, defined on the basis of a low capital cost per worker. If, however, the aim is to galvanize the industrial system, then the appropriate policy tool may be one directed at foscering the spread of modern SMl. An examintion of Latin American experiences with the design of policies for SM] shows that in mast cases the objective has been a shurt-term reduction in unemployment, with the assumpeion being that SM! use traditionat, labour-intensive technolugies; these policies ane therefore targeted at enterprises whose scales of production a re very small. However, this objective is not explicit; on the contrary, while it is supposed that the goral is to develop SM! but, in realiry, these units generally do not receive the intended benefits.

1"It should be borne in mind, that these elements are interdependent rather than autonomous.
} 
production are highly segmented. ${ }^{20}$ Thus, in the labour market there are segments of supply which may be of no more than marginal interest to large enterprises: the female labour force, unskilled manpower, young people, immigrants, etc. The capital market is relatively oligopolistic: intermediation between the supply and demand for capital is not a free-flowing process (as is also true of the availability of information) and depends on an organization which sometimes overvalues risk. The markets for the sale of products are also quite heterogeneous. One differentiating factor is the scope and distance of the markets, which may be either local and restricted or more extensive, and either national or international. Another factor influencing the segmentation of demand is the income level of consumers, since this dictates the characteristics of the products required.

The relations which firms have with the other economic actors and their relationship to the socioeconomic context determine the way in which production is organized. An enterprise's relations with other firms may be competitive, complementary or based on subcontracting and may either involve a high degree of economic and strategic dependence (directly, as in the case of subcontracting, or indirectly, in respect of which entity sets prices) or take the form of relations between autonomous units. ${ }^{21}$ The types of relations established with the State and its institutions, with the economy and with the society vary from one enterprise to another. These firms may occupy a position within the prevailing legal system, take advantage of benefits and fulfill duties defined by the State, or may

\footnotetext{
${ }^{20}$ Tokman (1987) provides a comprehensive review of the debate concerning the relationship berween the characteristics of these enterprises and markets for facturs of production.

"This subject is a very broad une and warrants a study of its own. There is no agreement as to the nature of these relations. Some experts think that a dependent relationship exists among these units similar to that seen between industria lized and developing countries, while ochers assert thar it is possible (and in fact has occurred) for micro-enterprises to maint ain autonomous telations with larger enterprises. Still others argue that some type of complementarity is feasible. See Tokman (1978), Sreel and Takagi (1983) and Bayce (1984). Fur a review of these subjects, see Tokman (1987). This subject involves considerations relating to marker charscteristics, corporate strategies, trends during different periods of the economic cycle, etc.
}

operate outside the system. They may utilize the natural resources and some characteris tics of the local markets to a greater or lesser extent and, finally, may either become deeply involved in the social environment and so take advantage of the local characteristics of the labour force or some cultural traditions, or may remain uninvolved in this respect.

As regards corporate strategies, a firm may have as its objective the maximization of total income, rather than aspiring to a level of profit such as that defined in capitalist terms (Tokman, 1987) or may adopt a survival strategy by which it seeks to maintain a minimum income (Cornia, 1987). It may also strive to increase its scale of production or simply to maintain the existing one. In addition, corporate strategies are differentiated by the time period they cover. The decisions taken in these respects will have an important influence on the way in which production is organized. ${ }^{22}$

An enterprise's form of internal organization is determined by the functions it performs and by the relationships that exist among factors of production. The functions of managing and directing an enterprise may be performed by a unit composed of professionals and/or by the entrepreneur, and may entail differing levels of complexity. The relationship between a firm's management and its workers and employees may be one of collaboration, thereby allowing for different degrees of information exchange and of the integration of capabilities, or may be markedly hierarchical or personalized. Finally, the capital/labour ratio may be of differing levels according to the composition of production, of the financial resources invested and of the

\footnotetext{
"Another, ispect of corporate strategy relates to a firm's position in the markets where it sells its products. This topic is relevant wo the definition of an SMI "paradigm", but is roo exten sive to exarnine in detail here. Nonet heless, mentiun, may be made of a few of the opinions held on the subject. In particular, there ane those who believe that SMls may position themselves in interstices of markets which large enterprises have abanduned because they are of no inrerest to them ('Tokman, 1978; Bayce, 1984) and those who feel that -depending upon the branch of production involved, the quality of the enterprise and the organization of the market in'questitun- SMls may be able to compete with large enterprises even when the respective products a re not entirely substitutable for one another (Streel and Takagi, 1983)
} 
techniques used (Staley and Morse, 1968, chap. 1 ). ${ }^{23}$

In summary, when viewed from the standpoint of their internal organization, firms may be classified according to the following scheme (only the most commonly-used terms are included here, rather than all the relevant terminology):

\begin{tabular}{|c|c|c|c|}
\hline $\begin{array}{l}\text { Household } \\
\text { production } \\
\text { system }\end{array}$ & $\begin{array}{l}\text { Cortage- } \\
\text { induscry } \\
\text { system }\end{array}$ & $\begin{array}{l}\text { Dispersed } \\
\text { production } \\
\text { system }\end{array}$ & $\begin{array}{l}\text { Factory } \\
\text { system }\end{array}$ \\
\hline $\begin{array}{l}\text { 1. Production } \\
\text { for own } \\
\text { use }\end{array}$ & $\begin{array}{l}\text { 2. Househoid- } \\
\text { based } \\
\text { corcage } \\
\text { industry } \\
\text { 3. Workshop- } \\
\text { based } \\
\text { cottage } \\
\text { industry }\end{array}$ & $\begin{array}{l}\text { 4. Household- } \\
\text { based } \\
\text { induscrial } \\
\text { work } \\
\text { 5. Small } \\
\text { dependent } \\
\text { or quasi- } \\
\text { dependent } \\
\text { workshop }\end{array}$ & $\begin{array}{l}\text { 6. Small } \\
\text { factury } \\
\text { 7. Medium. } \\
\text { scale } \\
\text { factury } \\
\text { 8. Large } \\
\text { factury }\end{array}$ \\
\hline
\end{tabular}

One useful distinction is that of small, medium-scale and large enterprises. This classi. fication cannot be rigid, but it should refer to some of the elements which have been described in the literature as being characteristic of firms of different sizes.

According to this scheme, small enterprises are those which, in so far as their internal organization is concerned, correspond to number 6 , although they may display some of the features attributed to number 5 . In these cases, the owner performs all (or a large part) of the activities involved in the management of the firm, and the enterprise's success is therefore closely linked to his entrepreneurial capabilities. The capital/labour ratio is low, although it varies according to the branch of production concerned, and the firm maintains a high level of technological flexibility. As regards their external relations, these enterprises normally choose nearby markets for

\footnotetext{
2'These elements are monifested in various concrete ways, including the form of ownership, which has a significant influence on the organization of production. Other differentiating factors relate to rechnology, which may be traditional and thus similar to that used in generations past, or mukern and thus closer to the technological "Frontier", Anocher factor is the firm's efficiency or lack thereof, which is not necessarily related to its modernity or traditionality, since depending on the branches of production and markets involved, there may be traditional rechnologies which are a]so efficient.
}

the sale of their products, although they may achieve national coverage or even export $t$ in this case too, past experience indicates that the potentials depend on the branch of production involved). Generally speaking, the objective of a small enterprise's strategy is not growth in terms of a more complex organization and a larger scale of production. ${ }^{24}$ The form of ownership is predominantly individual or that of a simple partnership.

The basic difference between a mediumscale enterprise and a small firm is one of strategy, in that the former seeks to increase its scale of production and broaden its markets. In a medium-scale enterprise, managerial functions are usually performed by more than one person, and its form of organization is necessarily more complex. Nonetheless, these units do maintain a certain degree of flexibility with respect to production.

A large enterprise is an industrial structure of a relatively large scale whose operational organization is diversified into specific units; its ownership structure is generally complex, and its organization of manpower is based on the division of labour. The strategy of such an enterprise is similar to that referred to in economic terminology as that of oligopoly or of imperfect competition, and it is usually active on national and international markets.

In the light of the above, the validity of some of the "adjectives" normally used to define SMI may be determined.

One aspect to be considered in this regards is the formal/informal dichotomy. An informal enterprise is characterized by "a rudimentary organization, lacking any clear-cut division of labour or of the ownership of the means of production; indeed, very little capital is committed and few skills are required. As regards its position in the market, it has ready access to competitive markets and to the ground level of concentrated markets; in these markets, because of the possibility of competition, average income is the adjustment variable. Given the limited size

${ }^{24}$ See Evans (1987) and Kumar (1985), The authors agree that the rates of growth of small production units vary widely. However, this tendency disappears as the size of the firms in question increises. In a ny event, the relationship between firm size and growrh is linked us the exonumy's stage of dereloprent. 
of the market, the greater the surplus of manpower, the lower the income earned by each person working in the sector" (Tokman, 1987). These enterprises' objective is to maximize income, and they tend to adopt a survival strategy (Cornia, 1987). However, this definition covers micro-enterprises as well, despire the fact that such firms are registered in censuses and maintain "formal" relations with markets and with the socioeconomic context. Enterprises are regarded as "informal" if they do not maintain relations with the State because they are attempting to evade, either totally or partially, the legal regulatory system of taxation. ${ }^{25}$

Finally, enterprises may be either modern or traditional. Generally, there is an implicit assumption that an enterprise is modern if it utilizes high technology and that large enterprises are modern while micro- and small enterprises are traditional. Nevertheless, many studies have been done which demonstrate the existence of large enterprises that use traditional technologies and of small enterprises that are in the technological vanguard. Moreover, the modernity of an enterprise is measured not only in terms of the technologies it employs, but also on the basis of the way in which its production is organized, the dynamism of the relations it establishes with the economy and the activeness of its role in the industrial development of a system.

The basic hypothesis proposed in this study is that a balanced industrial system is made up of enterprises of differing rypes and sizes and that modern SMJ is a good means of making that system more dynamic and of improving its internal articulation. Industrial policy should therefore take into account the functional differences among the various types of enterprises. In this article, consideration is given to that segment of SMl composed of modern enterprises or firms with the potential to undertake a modernization process. ${ }^{26}$

For our purposes here, SMIs will be defined in terms of the number of employees, since this indicator is easy to use and makes it possible to identify production units with a scale of production which is linked to an organization's level of complexity. This method of defining SMI undoubtedly fails to include all the variables specified above; nevertheless, it does provide a valid indicator for evaluating policy efficiency and studying the evolution of an industrial system.

\section{SMI in Latin America}

\section{SMI in the countries of Latin America and the OECD}

SMI has traditionally been an important part of the industrial structure of many countries, where it has represented more than $40 \%$ of total employment (see table 1). Hence the interest this subject has aroused in the ongoing debate concerning industrial policy and economic development.

\footnotetext{
"These are without question the ente cprises which are most frequently refer red to when micto-enterprises are under consideration. The role of the State in the economy is of enormous importance in regard to the definition of policies and strategic options, but it is not a subject whichcan be analysed in this article. However, a critical reading of the research project on Peru conducted by De Suto (1987) is recommended to the reader.
}

In analysing the available information concerning the OECD countries, two basic patterns clearly emerge from the range of experiences of these nations: on the one hand, there is the pattern represented by Italy and

\footnotetext{
${ }^{26}$ Cercainly, in many developing ountries enterprises having a limited scale of production are for the most part inefficient and techsologically behind-the-times, bur these are not inevitable characteristics of SMls. There are cases of industrial development in which $S M 1 s$ are in no way outshadowed by large enterprises in terms of productivity. technical efliciency and dynamison. Furthermore, when speaking of industrial policy, unly those encerprises are regarded as being useful for development which are in a position to promote it and, chus, assisnance prugrammes for "inefficient and non-dynamic" SMIs pursue sixial and employment objectives rather than the dynamization of the industrial system. See tCL.AC (1988) and Meller (1976).
} 
Table 1

SHARE OF SMI IN FORMAL INDUSTRIAL EMPLOYMENT, BY FIRM SIZE BASED ON NUMBER OF EMPLOYEES

(Percentages)

\begin{tabular}{|c|c|c|c|c|c|c|}
\hline \multirow{2}{*}{ Country } & \multirow{2}{*}{ Years } & \multicolumn{4}{|c|}{ Firms } & \multirow{2}{*}{$\begin{array}{l}\text { Employment } \\
\text { (thousands) }\end{array}$} \\
\hline & & $\begin{array}{c}\text { Under } \\
10\end{array}$ & $\begin{array}{c}\text { Under } \\
100\end{array}$ & $\begin{array}{c}\text { Under } \\
200\end{array}$ & $\begin{array}{c}\text { Under } \\
500\end{array}$ & \\
\hline \multicolumn{7}{|l|}{ Industrialized countries } \\
\hline $\begin{array}{l}\text { Federal Republic of Germany } \\
\text { Belgium } \\
\text { Denmark } \\
\text { United States } \\
\text { France } \\
\text { Japan } \\
\text { Italy } \\
\text { Sweden } \\
\text { United Kingdom }\end{array}$ & $\begin{array}{l}1984^{\circ} \\
1982 \\
1976^{b} \\
1976 \\
1972^{c} \\
1981^{d} \\
1981 \\
1978^{d} \\
1981\end{array}$ & $\begin{array}{l}18.6 \\
23.0\end{array}$ & $\begin{array}{l}18.0 \\
45.7 \\
32.0 \\
59.2 \\
59.3\end{array}$ & $\begin{array}{l}30.0 \\
55.4 \\
39.0 \\
74.3 \\
69.4 \\
40.7 \\
33.9\end{array}$ & $\begin{array}{l}50.0 \\
72.2 \\
44.6 \\
60.2 \\
80.4 \\
59.2\end{array}$ & $\begin{array}{r}8614 \\
905 \\
505 \\
21817 \\
5269 \\
13850 \\
5819 \\
984 \\
5773\end{array}$ \\
\hline \multicolumn{7}{|l|}{ Latin American countries } \\
\hline $\begin{array}{l}\text { Argentina } \\
\text { Brazil } \\
\text { Colombia } \\
\text { Costa Rica } \\
\text { Chile } \\
\text { Ecuador } \\
\text { El Salvador } \\
\text { Mexico } \\
\text { Peru } \\
\text { Uruguay } \\
\text { Venezuela }\end{array}$ & $\begin{array}{l}1984^{\circ} \\
1980 \\
1984^{\prime} \\
1975^{\prime} \\
1984 \\
1981 \\
1976^{\text {gh }} \\
1975 \\
1973 \\
1978 \\
1984^{b}\end{array}$ & $\begin{array}{l}19.6 \\
10.8 \\
18.0 \\
15.0 \\
39.7 \\
51.7 \\
16.8^{h} \\
19.6 \\
15.0 \\
20.0\end{array}$ & $\begin{array}{l}55.6 \\
46.0 \\
46.5 \\
12.8 \\
53.6 \\
62.0 \\
65.7 \\
38.0 \\
48.8 \\
51.0 \\
53.7\end{array}$ & $\begin{array}{l}74.3 \\
65.7 \\
59.4 \\
48.5 \\
68.0 \\
72.9\end{array}$ & $\begin{array}{l}80.4 \\
76.6 \\
58.7 \\
86.7 \\
86.1 \\
89.0 \\
69.7 \\
79.6 \\
81.0\end{array}$ & $\begin{array}{r}1677 \\
253 \\
183 \\
433\end{array}$ \\
\hline
\end{tabular}

Source: For Latin America, Italy and Federal Republic of Ciermany: national censuses. For Chile: World Bank, Cbile: small amd mediwm industro profect. July 1985. For OECD countries: OECD, lnnof ation in small and medinm firms, Paris, 1982. For Helgium: firtuder

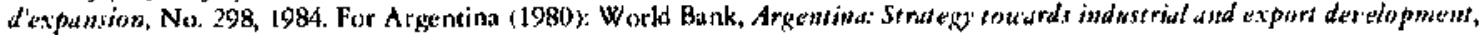
September 1985. Data concernisg ascal employment in OECD countries: OECD, Lubrow force statistics. Partis, 1983.

"Doses not cover firms having from I to 19 employees.

${ }^{h}$ Dexes not cover firms having from 0 to 5 employees.

'Does not cuvec firms with fewer thin 10 employees.

"Covers firms having from 0 to 299 employees.

300 employees and over.

Figures for firms with 0.10 employees are estimates.

${ }^{8}$ From 100 to $49 \%$ employees.

hFom I to 15 employees.

Japan, where SMI is an important part of the industrial structure; on the other hand, there is that of the Federal Republic of Germany and the United States, where the presence of SMI is significantly less notable and where there is a definite predominance of conglomerates which are highly diversified both horizontally and vertically. The use of indicators of participation in industrial activity brings out the difference in patterns of firm size even more clearly. Esti- mates for the early 1980 s indicate that enterprises employing fewer than 200 people accounted for a $20 \%$ share of industrial sales in the Federal Republic of Germany, whereas in Italy such firms had a $65 \%$ share. ${ }^{27}$

\footnotetext{
"Jaformation obtained from CONFINDUSTRLA, Sesto Rap. porto, Rome, 1983, and Statistisches Bundesamt, Federal Republic of Germany, 1986 census data.
} 
The cases of the other industrialized countries represent a number of variations on these themes: the situation in the United Kingdom is fairly similar to that of the Federal Republic of Germany, while the experiences of France, Belgium, Denmark and Sweden are more like those of Japan and Italy. The data also indicate that industries employing more than 500 people accounted for over $50 \%$ of employment in the Federal Republic of Germany and the United States, whereas in Italy, Japan and Denmark the corresponding figure was less than $30 \%$.

As in the case of the industrialized nations, a variety of situations are to be found in the countries of Latin America with the difference that in some of them the stratum of micro-enterprises is significant. On one side, there are the economies (such as El Salvador, Ecuador and, to a lesser extent, Peru) with a less developed industrial sector in which nearly one-half of total employment is in formal micromenterprises (fewer than 10 employees). On the other, there are the more industrialized economies such as Brazil, Mexico, Colombia and Venezuela in which large enterprises (over 100 employees) account for an important share of employment (around $60 \%$ of all industrial jobs) and which thus exhibit a distribution pattern similar to that of the Federal Republic of Germany. $A$ third category is made up of countries at an intermediate level of industrialization, and it is in these countries (the most notable examples being Chile, Argentina and Uruguay) that SMI carries the greatest relative weight.

The above facts, when considered in combination with the specific features of each of the countries, suggest the existence of some type of relationship between firm size, on the one hand, and industrial dynamism, articulation and underemployment, on the other. ${ }^{28}$ Microenterprises have a greater presence in those countries exhibiting an insufficient process of accumulation and unstable industrial growth; as a result of these circumstances, in the 1980 s these countries have recorded the highest rates of underemployment in the region. The pres-

\footnotetext{
20 The term "underemployment" is understood as referring to the performance of work whose productivity, as wel] as the eamings it provides, is insufficient and/or which does not adequately urilize workers' capabilities. See PREALC (1982).
}

ence of large enterprises is most significant in the countries which have experienced greater industrial growth but which also suffer from the highest levels of social disarticulation, measured in terms of unequal distribution (Chenery et al., 1974; García, 1984; Fajnzylber, 1987). In contrast, SMI are an important presence in the industrial structures of countries which have traditionally had high levels of urbanization, industrialization and articulation but whose economies have stagnated in the course of the past few decades. ${ }^{29}$

Judging by the figures, the entrepreneurial structures of some Latin American countries have similarities to those of the industrialized nations; however, the substantially different contexts associated with these two groups of nations must not be overlooked. There have been enormous structural differences between the growth and accumulation processes of the two, the specific features of their incorporation of the labour force, the articulation of their production systems and their attitudes to technical progress. Although it is not our purpose here to delve into each of these subjects, the prevailing feeling, although it varies somewhat from one country to another, is that the industrialization strategies used in Latin America have fostered the re-creation of a production apparatus having many features that are dysfunctional in relation to local needs and resources, with limited dynamism and low levels of productivity and competitiveness, and that over time this has weakened the production base and diminished these countries' ability to create new enterprises and jobs. ${ }^{30}$

The most visible and controversial phenomena in this respect are the important role of the urban informal sector and the low productivity of the modern sector. If the category of microenterprises is extended to include informal employment in industry, which by definition is

\footnotetext{
29During the period 1950-1980, the average growth tate for the manufacturing industry was: Brazil, $83 \%$; Mexico, $7.5 \%$; Colombia, $6.0 \%$; Venezuela, $7.2 \%$; Chile, $3.6 \%$; Argentina, $3.6 \%$; and Utuguay, $2.6 \%$, while the average for Latio $A$ merica was $6.7 \%$ (ECLAC). The most significant levels of underemphyment are found in Ecuador, 62\%: Peru, 51.6\%; and EI Salvador, 49\%; these rates ate much higher than the regional average $(38 \%)$. The above figures represent the percentage of the economically active population which is subjece to underemploymene (PREALC).

30Fur a more detailed discussion of the subject, see Fajnzylber (1983 and 1987), Ikonicoff (1987) and Vuskovic (1985).
} 
Table 2

\section{DISTRIBUTION OF TOTAL INDUSTRIAL EMPLOYMENT BY FIRM SIZE}

(Percentages)

\begin{tabular}{|c|c|c|c|c|}
\hline \multirow{2}{*}{ Country and year } & \multicolumn{3}{|c|}{ Number of employees } & \multirow{2}{*}{$\begin{array}{l}\text { Level of } \\
\text { industrializarion }\end{array}$} \\
\hline & $\begin{array}{c}0-9 \\
\text { and informal }\end{array}$ & $10 \cdot 99$ & $\begin{array}{c}100 \\
\text { and over }\end{array}$ & \\
\hline \multicolumn{5}{|l|}{ Large countries } \\
\hline Argenrina (1984) & 43.7 & 25.2 & 31.1 & 27.1 \\
\hline Brazil $(1980)$ & 38.3 & 24.3 & 37.4 & 29.1 \\
\hline Mexico (1975) & 54.1 & 11.5 & 34.4 & 24.3 \\
\hline \multicolumn{5}{|c|}{ Medium-sized countries } \\
\hline Colombia (1984) & 46.7 & 18.5 & 34.8 & 20.2 \\
\hline Chile (1984) & 40.5 & 27.0 & 32.5 & 21.3 \\
\hline Peru (1973) & 55.3 & 16.2 & 28.5 & 24.3 \\
\hline Uruguay (1978) & 26.1 & 31.0 & 42.9 & 26.6 \\
\hline Venezuela (1984) & 32.0 & 28.7 & 39.3 & 19.7 \\
\hline \multicolumn{5}{|l|}{ Small countries } \\
\hline Costa Rica (1975) & 33.7 & 27.1 & 39.2 & 20.1 \\
\hline Ecuador (1981) & 51.7 & 17.8 & 30.5 & 23.1 \\
\hline El Salvador (1976) & 65.8 & 9.9 & 24.3 & 19.9 \\
\hline
\end{tabular}

Source: Manufacturing censuses and industrial surveys. The data un total employment were calculated on the basis of information provided by 11.0 and ECLAC. Levels of industrialization were obtained from the foint ECLAC/UNIDO lndustry and Techmology Division.

not reflected in censuses of the manufacturing industry, ${ }^{31}$ then the distribution of firms by size becomes markedly skewed (see table 2 ). On this basis, the proportion of employment in the manufacturing sector accounted for by microenterprises ranges from $26 \%$ in Uruguay to $66 \%$ in El Salvador, with the share of employment corresponding to micro-enterprises increasing the most in Peru, Mexico and Colombia.

In order for the comparison between SMI in the Latin American and the industrialized countries to be a more realistic one, however, it is also necessary to take into consideration the socioeconomic contexts involved.

\section{Brazil, Colombia and Chile}

There are a number of trends and features which are characteristic of the Latin American pattern of industrialization. The trends observed during

\footnotetext{
"In many cases this limirarion is due to the lack of industrial censuses or to their incomplete coverage. These estimates ane based on data provided by induserial surveys and sectoral employment figures calculared by 110 un the basis of popularion censuses and household surveys.
}

the past three decades have been associated with rapid urbanization, an increase in the rate of investment and the degree of industrialization, a failure on the part of modern sectors to create enough jobs, and a widening of the productivity gap between the modern industrial sector and services. Common traits have included a position in the international economy which is based on natural resources, the establishment of an industrial structure oriented towards the domestic market, the desire to reproduce consumption patterns typical of the advanced countries and the precarious position of national entrepreneurs (García and Tokman, 1985; Fajnzylber, 1987).

Despite the dynamism of industrial growth and of the accumulation process in Latin America since the $1950 \mathrm{~s}$, this has not been enough to uphold a level of production comparable to that of the industrialized countries. ${ }^{32}$ Notwithstand-

\footnotetext{
32Whereas in 1950 the per capita producr of the European countries was three times that of Latin America, in the 1980 s it has been almost four times as great. Between 1960 and 1980 Latin America's industrial productivity incressed ar an average a nnual rate of $2.9 \%$, while that of the EEC countries rose at a rate of $4.4 \%$ (estimares based on information from ECL.AC and OECD).
} 
ing these factors which the countries have in common, however, it is essential to consider the specific features of the different national experiences as well. This diversity is exemplified by the industrialization processes of Brazil, Colombia and Chile, particularly with respect to the role played by SMI in these processes.

\section{a) Industrial growth and SMI}

With a population of over 130 million, Brazil has a per capita product of about US\$1 600. Thanks to a prolonged and sustained industrial and technological development effort, it has joined the ranks of the newly industrializing countries (NICs). At present the country has a trade surplus in the agricultural, mining and industrial sectors. Colombia, with a population of 29 million and a per capita product of US $\$ 1300$, has pursued an industrialization strategy which is notable for its stability. Its trade balance shows a surplus in the agricultural sector, a deficit in manufacturing and is at equilibrium in the energy sector. Chile, with a population of 12 million and a per capita producr of US\$1 400 , has adopted a liberal approach which has entailed sweeping changes in the economy, and has a surplus in agriculture and mining and a deficit in industry and energy.

The process of industrial expansion in Brazil during the past few decades has advanced rapidly in two main areas. Under the Target Plan (19561961), growth was concentrated in the transport materials sector; then beginning with the structural adjustment called for in the Second Development Plan (1974), an extremely rapid expansion was seen in the installed capacity of heavy industry oriented towards capital goods and strategic inputs, with the historical growth rate reaching $8.5 \%$ annually. In the $1980 \mathrm{~s}$, however, this rate has dropped to $3 \%$ (Tavares and Coutinho, 1985).

Colombia was one of the first Latin American countries to undertake an export promotion policy, and this policy produced satisfactory results between 1967 and 1974. Thereafter, however, even though the strategy remained substantially the same, the economy tended to stagnate as a consequence of both internal and external factors. ${ }^{33}$ The historical growth rate, which stood at $6 \%$ up to the 1970 s, has fallen to $2.5 \%$ in the $1980 \mathrm{~s}$.
A major change began to take place in 1975 in the traditional pattern of Chilean industry, which had been based on the execution of large public investment projects promoted by CORFO (iron and steel, copper refining, perroleum, sugar and wood pulp plants) and the development of the domestic market. In the mid-1970s the industrial system began to play a part as one of the components of an overall strategy aimed at opening up the economy to the outside world, deregulating the financial system and readjusting the size of the State sector. The average industrial growth rate, which had been around $5 \%$ until that time, started on a downward slide marked by sharp fluctuations; a subsequent upturn brought the average growth rate to $1 \%$ in the 1980s (Muñoz, 1986).

The effects of the last crisis were felt more intensely in Chile than in Brazil and Colombia. The countries' recoveries have also differed: the industrial growth rate for the period 1984-1986 was $9 \%$ per year in Brazil, $5 \%$ in Colombia and $4.5 \%$ in Chile. In 1960, Brazil's manufacturing output was five times that of Colombia and of Chile; currently, it is nine and 13 times greater, respectively.

The trend with respect to SMI has also been different in each of these cases. (The reader will recall that Brazil and Colombia were classified among those Latin American countries in which large enterprises have been a more important factor, whereas Chile was included in the group of countries in which SMI has been relatively significant.) In all these countries, governmental agencies have promoted SMI, through the Corporación Financiera Popular en Colombia, SERCOTEC in Chile and CEBRAE in Brazil.

Brazil's process of industrial expansion has involved a strengthening of the structure of large enterprises, and employment in such firms has risen more rapidly than in other enterprises (see table 3). Much the same thing was occurring in Colombia, until the adjustment made in the 1980 s reversed this trend. The situation in Chile,

\footnotetext{
"The above is a simplified picture of the situation, inasmuch as the various governments have emphasized different economic aspects: C. Lleras (1967-1970), economic openness; M. Pastrana (1970-1974), urban construction; A. López (1974-1978), the distributive situation; Turbay (1978-1982), regional aptonomy; and Betancur, short-term balances. See Berry and Thoumi (1986).
} 
Table 3

BRAZIL, COLOMBIA AND CHILE: VARIATION IN AVERAGE ANNUAL EMPLOYMENT IN THE MANUFACTURING SECTOR, BY FIRM SIZE

(Percentages)

\begin{tabular}{|c|c|c|c|c|c|}
\hline \multirow{2}{*}{$\begin{array}{c}\text { Firm } \\
\text { size } \\
\text { (number of } \\
\text { employees) }\end{array}$} & \multicolumn{2}{|c|}{ Brazil } & \multicolumn{2}{|c|}{ Colombia } & \multirow{2}{*}{$\begin{array}{c}\text { Chile }^{a} \\
1967- \\
1979\end{array}$} \\
\hline & $\begin{array}{l}195 \% \\
1974\end{array}$ & $\begin{array}{l}1975 . \\
1980\end{array}$ & $\begin{array}{l}1960 . \\
1975\end{array}$ & $\begin{array}{l}1979 \\
1984\end{array}$ & \\
\hline $5-49$ & 3.2 & 5.1 & 1.0 & - & -0.1 \\
\hline $50-99$ & 6.1 & 4.5 & 4.8 & -0.6 & -0.3 \\
\hline 100 and over & 5.3 & 5.8 & 5.6 & -2.0 & -0.5 \\
\hline Tutal & 4.9 & 5.3 & 4.2 & - & -0.4 \\
\hline
\end{tabular}

Source: Esrimates based on industrial censuses and surveys.

${ }^{4}$ In Chite, the relevant caregories are $5-9,10-49$ and 50 or more employees.

however, has been substantially different: dur* ing the period 1967-1979, a contraction in industry was observed at the same time that a significant restructuring of employment in the manufacturing sector was taking place; this process called for adjustments in all types of enterprises, particularly the larger ones.

\section{b) SMI in the industrial structure}

One of the characteristics of SMIs is their subordination to the sectoral structure of the economy. This means that, in disaggregated terms, their position in the industrial structure may fall within the modern/traditional, urban/rural, formal/informal and export/domestic market spectrums. Although the information in this respect concerning the countries of the region is still of a preliminary nature, there are nonetheless some very telling indications that this is the case.

First of all, there are the changes which have been seen in the sectoral profiles of industry as a whole. The most significant of these is the increase in the size of the capital goods sector in Brazil (from 10\% to $19 \%$ between 1963 and 1985). Generally specaking, Colombia and Chile have retained their industrial profiles of the $1960 \mathrm{~s}$, although the importance of the capital goods sector has grown slightly in the case of Colombia (from $5 \%$ to $6 \%$ ), while in Chile it has dropped from 6\% to $4 \%$ (ECLAC/UNIDO, 1987).

At first glance, the available information concerning the relative importance of SMI, broken down by major branches of production, ${ }^{34}$ does not reflect differences among the three pairs which would be commensurate with the degree of the contrasts existing at the industrial level (see table 4). However, there are interesting distinctions of an intermediate degree. The first has to do with the sectoral emphases of SMI, while the second concerns productivity ratios.

In Brazil there is a greater concentration of small industrial enterprises -10 to 49 employees - in the consumer goods sector, and particularly in the furniture, printed matter and food industries. This trait is even more notable in Chile, where small industry represents a large share of the clothing and plastics sectors, in addition to furniture and foodstuffs. The above suggests that some type of relationship exists between the production of goods to meet basic needs and small-scale enterprise. In the case of Colombia, the presence of small industrial enter. prises is more notable in the capital goods industries, and particularly in the areas of non-electrical machinery and precision instruments. In Chile, too, small enterprises are beginning to be a force in the production of precision instruments and metal products.

These data also indicate that medium-scale industry is more evenly distributed among the various sectors in Brazil. In this country, such industry is primarily oriented towards the production of intermediate goods (wood, paper and chemicals) and capital goods (mechanical items); in Chile, it tends towards capital goods (metal products and precision instruments), as is also true in Colombia (non-electrical machinery and precision instruments). These variations would appear to be related to these enterprises' relative capacity for modernization, which allows them to produce more complex goods.

In the most industrialized production structure, i.e., that of Brazil, one notable feature is the

${ }^{34}$ The fullowing ISIC categories were used: Consumer goods: $311-12,313,314,322,324,332,342,352,356,361$ and $39 ;$ Intermediate goods: $321,323,331,341,351,353,354,355,362,369,37 \mathrm{l}$; Capital goods: $381,382,383,384$ and 385. In the cose of Brazil which uses different categuries, the metallurgical industry and miscellaneous industries were not clnssified. 
Table 4

PATTERN OF EMPLOYMENT, VALUE ADDED, INVESTMENT AND RELATIVE PRODUCTIVITY OF SMI IN BRAZIL,

CHILE AND COLOMBIA BY SIZE OF FIRM ACCORDING TO SECTOR OF PRODUCTION

\begin{tabular}{|c|c|c|c|c|c|c|c|c|c|c|c|c|c|c|c|c|c|c|}
\hline \multirow{2}{*}{$\begin{array}{l}\text { Industrial } \\
\text { branches } \\
\text { (ISIC 2) } \\
\text { by sector } \\
\text { of priducrion }\end{array}$} & \multicolumn{3}{|c|}{$\begin{array}{l}\text { Employment (\%) by } \\
\text { firm size }\end{array}$} & \multicolumn{3}{|c|}{ Value added $(\%)$} & \multicolumn{3}{|c|}{ Net investment $(\%)$} & \multicolumn{4}{|c|}{$\begin{array}{l}\text { Prodictivity index } \\
\text { (firm size }=100)\end{array}$} & \multicolumn{4}{|c|}{$\begin{array}{l}\text { Productivity index } \\
\text { (induscrial branch }=100 \text { ) }\end{array}$} & \multirow{2}{*}{$\begin{array}{l}\text { \%o of } \\
\text { toral } \\
\text { value } \\
\text { added } \\
\text { gener } \\
\text { ated } \\
\text { by } \\
\text { beances }\end{array}$} \\
\hline & $10-49$ & $50-99$ & $\begin{array}{l}100 \\
\text { and } \\
\text { over }\end{array}$ & $10-49$ & $30-99$ & $\begin{array}{l}100 \\
\text { and } \\
\text { over }\end{array}$ & $10-49$ & $50-99$ & $\begin{array}{l}100 \\
\text { and } \\
\text { over }\end{array}$ & $10-49$ & $30-99$ & $\begin{array}{l}100 \\
\text { and } \\
\text { over }\end{array}$ & $\begin{array}{c}\text { Aver- } \\
\text { age }\end{array}$ & 10.49 & $50-99$ & $\begin{array}{l}100 \\
\text { and } \\
\text { over }\end{array}$ & $\begin{array}{l}\text { Aver- } \\
\text { age }\end{array}$ & \\
\hline $\begin{array}{l}\text { Brazil 1975 } \\
\text { Consumer goods } \\
\text { Intermediate goods } \\
\text { Capical goods } \\
\text { Nos dassified } \\
\text { Tocal }\end{array}$ & $\begin{array}{l}30.2 \\
27.3 \\
17.3 \\
21.6 \\
25.1\end{array}$ & $\begin{array}{l}149 \\
15.6 \\
13.9 \\
15.3 \\
14.9\end{array}$ & $\begin{array}{l}54.9 \\
57.1 \\
68.8 \\
63.1 \\
60.0\end{array}$ & $\begin{array}{l}22.0 \\
20.3 \\
14.0 \\
15.0 \\
18.5\end{array}$ & $\begin{array}{l}13.6 \\
15.5 \\
11.5 \\
12.6 \\
13.6\end{array}$ & $\begin{array}{l}64.4 \\
64.2 \\
74.5 \\
72.4 \\
67.9\end{array}$ & & & & $\begin{array}{r}89 \\
109 \\
112 \\
96 \\
100\end{array}$ & $\begin{array}{r}90 \\
118 \\
93 \\
93 \\
100\end{array}$ & $\begin{array}{r}93 \\
107 \\
98 \\
104 \\
100\end{array}$ & $\begin{array}{r}90 \\
108 \\
102 \\
102 \\
100\end{array}$ & $\begin{array}{l}73 \\
74 \\
81 \\
69 \\
74\end{array}$ & $\begin{array}{r}91 \\
100 \\
83 \\
83 \\
91\end{array}$ & $\begin{array}{l}117 \\
112 \\
108 \\
119 \\
113\end{array}$ & $\begin{array}{l}100 \\
100 \\
100 \\
100 \\
100\end{array}$ & $\begin{array}{r}29 \\
33 \\
24 \\
15 \\
100\end{array}$ \\
\hline $\begin{array}{l}\text { Brazil } 1980^{\circ} \\
\text { Consumer goods } \\
\text { lotermediate goods } \\
\text { Capital goods } \\
\text { Not classified } \\
\text { Total }\end{array}$ & $\begin{array}{l}31.1 \\
28.2 \\
15.8 \\
21.1 \\
25.1\end{array}$ & $\begin{array}{l}144 \\
14.9 \\
13.0 \\
14.4 \\
14.2\end{array}$ & $\begin{array}{l}54.6 \\
56.9 \\
71.2 \\
64.5 \\
60.7\end{array}$ & $\begin{array}{l}19.1 \\
17.7 \\
10.2 \\
12.1 \\
15.4\end{array}$ & $\begin{array}{r}14.3 \\
13.8 \\
9.6 \\
11.1 \\
12.5\end{array}$ & $\begin{array}{l}66.6 \\
68.5 \\
80.2 \\
76.8 \\
72.1\end{array}$ & & & & $\begin{array}{r}79 \\
123 \\
109 \\
95 \\
100\end{array}$ & $\begin{array}{r}89 \\
126 \\
87 \\
89 \\
100\end{array}$ & $\begin{array}{r}81 \\
122 \\
98 \\
102 \\
100\end{array}$ & $\begin{array}{r}79 \\
120 \\
104 \\
101 \\
100\end{array}$ & $\begin{array}{l}61 \\
63 \\
64 \\
57 \\
61\end{array}$ & $\begin{array}{r}100 \\
93 \\
74 \\
78 \\
88\end{array}$ & $\begin{array}{l}122 \\
120 \\
113 \\
119 \\
119\end{array}$ & $\begin{array}{l}100 \\
100 \\
100 \\
100 \\
100\end{array}$ & $\begin{array}{r}26 \\
35 \\
25 \\
14 \\
100\end{array}$ \\
\hline $\begin{array}{l}\text { Chile } 1979 \\
\text { Consumer goods } \\
\text { Incermediate goods } \\
\text { Capital goods } \\
\text { Total }\end{array}$ & $\begin{array}{l}34.3 \\
23.6 \\
26.3 \\
29.2\end{array}$ & $\begin{array}{l}65.7 \\
76.4 \\
73.7 \\
70.8\end{array}$ & & $\begin{array}{r}15.3 \\
8.6 \\
15.2 \\
12.4\end{array}$ & $\begin{array}{l}84.7 \\
91.4 \\
84.8 \\
87.6\end{array}$ & & $\begin{array}{l}83.4 \\
91.1 \\
95.6 \\
86.5\end{array}$ & $\begin{array}{r}16.6 \\
8.9 \\
4.4 \\
13.5\end{array}$ & & $\begin{array}{r}96 \\
106 \\
103 \\
100\end{array}$ & $\begin{array}{r}95 \\
118 \\
71 \\
100\end{array}$ & & $\begin{array}{r}92 \\
123 \\
76 \\
100\end{array}$ & $\begin{array}{l}45 \\
37 \\
58 \\
42\end{array}$ & $\begin{array}{l}129 \\
120 \\
115 \\
124\end{array}$ & & $\begin{array}{l}100 \\
100 \\
100 \\
100\end{array}$ & $\begin{array}{r}45 \\
43 \\
12 \\
100\end{array}$ \\
\hline $\begin{array}{l}\text { Chile } 1984 \\
\text { Consumer goods } \\
\text { Intermediate goods } \\
\text { Capiral goods } \\
\text { Total }\end{array}$ & $\begin{array}{l}33.4 \\
23.4 \\
30.5 \\
29.7\end{array}$ & $\begin{array}{l}17.1 \\
11.5 \\
19.5 \\
15.6\end{array}$ & $\begin{array}{l}49.5 \\
65.1 \\
50.0 \\
54.6\end{array}$ & $\begin{array}{r}15.9 \\
6.8 \\
21.6 \\
11.8\end{array}$ & $\begin{array}{r}15.4 \\
4.8 \\
20.2 \\
10.5\end{array}$ & $\begin{array}{l}68.7 \\
88.4 \\
58.2 \\
77.7\end{array}$ & $\begin{array}{r}16.7 \\
5.6 \\
13.0 \\
11.3\end{array}$ & $\begin{array}{r}19.4 \\
2.9 \\
17.6 \\
11.7\end{array}$ & $\begin{array}{l}63.9 \\
91.5 \\
69.4 \\
77.0\end{array}$ & $\begin{array}{r}96 \\
113 \\
97 \\
100\end{array}$ & $\begin{array}{r}107 \\
96 \\
84 \\
100\end{array}$ & $\begin{array}{r}78 \\
147 \\
44 \\
100\end{array}$ & $\begin{array}{r}80 \\
154 \\
54 \\
100\end{array}$ & $\begin{array}{l}48 \\
29 \\
71 \\
40\end{array}$ & $\begin{array}{r}90 \\
42 \\
104 \\
67\end{array}$ & $\begin{array}{l}139 \\
136 \\
116 \\
142\end{array}$ & $\begin{array}{l}100 \\
100 \\
100 \\
100\end{array}$ & $\begin{array}{r}42 \\
50 \\
8 \\
100\end{array}$ \\
\hline $\begin{array}{l}\text { Colombia } 1975 \\
\text { Consumer goods } \\
\text { Intermediate goods } \\
\text { Capital goods } \\
\text { Total }\end{array}$ & $\begin{array}{l}22.4 \\
14.2 \\
25.4 \\
19.9\end{array}$ & $\begin{array}{l}14.3 \\
10.0 \\
18.2 \\
13.4\end{array}$ & $\begin{array}{l}63.3 \\
75.8 \\
56.4 \\
66.7\end{array}$ & $\begin{array}{r}9.9 \\
6.8 \\
12.1 \\
9.0\end{array}$ & $\begin{array}{r}10.0 \\
5.7 \\
13.6 \\
8.9\end{array}$ & $\begin{array}{l}\mathbf{8 0 . 1} \\
87.4 \\
74.3 \\
82.1\end{array}$ & $\begin{array}{r}13.8 \\
7.5 \\
9.6 \\
10.5\end{array}$ & $\begin{array}{r}7.6 \\
1.4 \\
19.4 \\
6.4\end{array}$ & $\begin{array}{l}78.6 \\
91.1 \\
71.0 \\
83.1\end{array}$ & $\begin{array}{r}99 \\
109 \\
92 \\
100\end{array}$ & $\begin{array}{r}107 \\
89 \\
98 \\
100\end{array}$ & $\begin{array}{r}105 \\
97 \\
94 \\
100\end{array}$ & $\begin{array}{r}102 \\
103 \\
88 \\
100\end{array}$ & $\begin{array}{l}44 \\
48 \\
48 \\
45\end{array}$ & $\begin{array}{l}70 \\
37 \\
75 \\
67\end{array}$ & $\begin{array}{l}127 \\
115 \\
132 \\
123\end{array}$ & $\begin{array}{l}100 \\
100 \\
100 \\
100\end{array}$ & $\begin{array}{r}47 . \\
38 \\
15 \\
100\end{array}$ \\
\hline $\begin{array}{l}\text { Colombia } 1979 \\
\text { Consumer goods } \\
\text { Intermediate goods } \\
\text { Capital goods } \\
\text { Total }\end{array}$ & $\begin{array}{l}19.3 \\
13.6 \\
21.5 \\
17.8\end{array}$ & $\begin{array}{r}14.8 \\
9.5 \\
16.4 \\
13.3\end{array}$ & $\begin{array}{l}65.9 \\
77.0 \\
62.1 \\
68.9\end{array}$ & $\begin{array}{r}8.0 \\
6.3 \\
11.4 \\
7.8\end{array}$ & $\begin{array}{r}8.5 \\
5.3 \\
12.7 \\
7.8\end{array}$ & $\begin{array}{l}83.6 \\
88.4 \\
75.9 \\
84.4\end{array}$ & $\begin{array}{r}16.8 \\
5.7 \\
13.6 \\
11.4\end{array}$ & $\begin{array}{r}10.1 \\
7.4 \\
12.7 \\
9.3\end{array}$ & $\begin{array}{l}73.0 \\
87.0 \\
73.8 \\
79.3\end{array}$ & $\begin{array}{r}94 \\
121 \\
91 \\
100\end{array}$ & $\begin{array}{r}97 \\
108 \\
99 \\
100\end{array}$ & $\begin{array}{r}103 \\
107 \\
75 \\
100\end{array}$ & $\begin{array}{r}100 \\
114 \\
75 \\
100\end{array}$ & $\begin{array}{l}41 \\
46 \\
53 \\
44\end{array}$ & $\begin{array}{l}57 \\
56 \\
77 \\
59\end{array}$ & $\begin{array}{l}127 \\
115 \\
122 \\
122\end{array}$ & $\begin{array}{l}100 \\
100 \\
100 \\
100\end{array}$ & $\begin{array}{r}47 \\
38 \\
14 \\
100\end{array}$ \\
\hline $\begin{array}{l}\text { Colombia } 1984 \\
\text { Consumer gouds } \\
\text { lncermediate goods } \\
\text { Capital goods } \\
\text { Total }\end{array}$ & $\begin{array}{l}23.1 \\
15.0 \\
23.2 \\
20.6\end{array}$ & $\begin{array}{l}15.4 \\
11.3 \\
15.6 \\
14.1\end{array}$ & $\begin{array}{l}61.5 \\
73.7 \\
61.1 \\
65.2 \\
\end{array}$ & $\begin{array}{r}9.0 \\
6.7 \\
12.1 \\
8.6 \\
\end{array}$ & $\begin{array}{r}9.4 \\
6.9 \\
11.7 \\
8.8 \\
\end{array}$ & $\begin{array}{l}81.6 \\
86.4 \\
76.3 \\
82.6\end{array}$ & $\begin{array}{r}12.6 \\
2.4 \\
10.7 \\
7.5 \\
\end{array}$ & $\begin{array}{r}16.3 \\
4.0 \\
13.1 \\
10.1 \\
\end{array}$ & $\begin{array}{l}71.1 \\
93.6 \\
76.2 \\
82.5 \\
\end{array}$ & $\begin{array}{r}95 \\
120 \\
93 \\
100 \\
\end{array}$ & $\begin{array}{r}99 \\
110 \\
89 \\
100 \\
\end{array}$ & $\begin{array}{r}106 \\
104 \\
73 \\
100 \\
\end{array}$ & $\begin{array}{r}101 \\
112 \\
74 \\
100 \\
\end{array}$ & $\begin{array}{l}39 \\
44 \\
52 \\
42 \\
\end{array}$ & $\begin{array}{l}61 \\
61 \\
75 \\
62\end{array}$ & $\begin{array}{l}133 \\
117 \\
125 \\
127\end{array}$ & $\begin{array}{l}100 \\
100 \\
100 \\
100\end{array}$ & $\begin{array}{r}52 \\
35 \\
13 \\
100\end{array}$ \\
\hline
\end{tabular}

By careguries based on number of employees.

investmeat.

'The census classification groups together all firms having over 50 employees. 
major role played by large enterprises in the production of capital goods. The subsectors in which large production units figure prominently (electrical and transport equipment) are precisely those branches whose technological complexity is the greatest.

In addition, whereas in Brazil the productivity of small-scale industry - value added per employee - is relatively high in the intermediate (chemicals) and capital (electrical machinery) sectors, in the other two countries this is only true with respect to intermediate goods, i.e., in those branches in which SMIs play a minor role. As regards medium-scale enterprise, high rates of productivity tend to be concentrated in the intermediate goods sectors: chemicals in Brazil; chemicals and paper in Colombia; chemicals and basic industry in Chile. In relation to large firms, the highest rate of productivity is found in intermediate goods (chemicals and paper) in Brazil; in consumer products (tobacco, beverages and chemicals) and intermediate goods (paper, petroleum and basic industry) in Colombia; and in intermediate goods (petroleum, non-ferrous metals and paper) in Chile.

In Brazil, the productivity of SMI vis-a-vis that of large-scale enterprise is relatively low on average: $1.9 \%$ for small industry and $1.3 \%$ for medium-scale industry. The differences in productivity are substantially greater in Colombia and Chile.

When the figures corresponding to Brazil are broken down, it may be seen that the productivity ratios remain much the same in the relevant subsectors. It would thus be of interest to take a closer look at the conditions for the macroeconomic survival of small enterprises in Brazil, particularly in relation to the way in which these enterprises coexist with one another and with large firms.

\section{c) The performance of SMI}

According to the overall information for Latin America, SMI has a very limited position in the international economy, shows a preference for domestic markets and generally does not play a leadership role in the economic, political or institutional spheres, in contrast to the influence exerted by large private corporations, transnational corporations and public enterprises (Tou- raine, 1987; ECLAC/UNIDO, 1985; Estrada and Masi, 1983).

General analyses of the region as a whole usually associate most of the countries with a pattern marked by a specialization of production oriented towards mass consumer goods, the utilization of rudimentary technology and a lack of inter-enterprise co-operation. Within firms, these factors give rise to inadequate production conditions, an extraordinarily conservative management approach, a detrimental form of dependency on input and product markets, problems of gaining access to financing, and a low level of manpower skills.

Nevertheless, a thorough analysis of these experiences indicates the existence of a variety of situations. ${ }^{35}$ In Brazil, SMI developed with the help of an expanding domestic market, and medium-scale industries which produce intermediate goods are prominent. In Colombia, a relative shift of large enterprise within the domestic market was what paved the way for SMI, which has achieved a significant position in the capital goods sector. Finally, in Chile SMI has found it necessary to fall back on a survival strategy owing to this country's industrial reorganization, but it has nonetheless continued to account for a significant share of the production of capital goods. In all of these countries, SMIs have a limited technological level, primarily use their own capital, are averse to borrowing and see the governmental sector as performing more of a regularatory than a promotional function. The fact that SMI in these countries have nonetheless made a highly positive contribution is attributable to the existence of relatively stable macroeconomic policies which favour industry in general, and to an economic environment which has provided these enterprises with a steadily growing market and has allowed them to attain a systematic improvement in their productivity (Gómez, 1986). Recently, SMIs have concentrated their efforts on upgrading their technologies. At the same time, they have been increasing their demands for State support in

"Some relevant studies concerning SMI at the national level are the following: Argentina: Minisrry of Planning (1984); Brazil: Schmitz (1982); Columbia: Cortéx, Berty and Ishag (1987); Chile; Castillo (1986); Ecuador: INSDTEC (1986); Peru: JUNAC (1987); Venezuela: JUNAC (1986). 
the areas of financing, technical assistance and export promotion.

In Colombia, the contribution made by SMI to employment and output in the manufacturing sector has been a moderate one. The development of these production units began to pick up sharply when a policy aimed at opening up the economy was launched in the late 1960s. Although promoting SMI was not one of the objectives of this process, it did make things easier for SMI, because large enterprises began to specialize in the external market and in one part of the national market, thereby leaving a considerable segment of domestic demand unmet. This situation encouraged many technicians, employees and professionals to start their own companies, especially since it was accompanied by the emergence of a market in second-hand machinery, much of which came from large enterprises that had embarked on a modernization drive (Escandón, 1981). With the crisis of the 1980s, SMI productivity levels began to fall, but it has nonetheless retained its potential with respect to capital goods.
In Chile, SMI has had to deal with a number of traumatic events. Unlike what occurred in the other two countries, SMI consolidated its position in the Chilean industrial structure during the 1960 s and diversified its activities among consumer, intermediate and capital goods within a context of slow economic growth. However, its development was associated with an intensive process of import substitution and a heavy dependence on promotion and assistance policies instituted by the State. This was the position of SMI when, in 1975, it found itself confronted with an abrupt restructuring of the economy which included a rapid opening-up of trade, financial deregulation and the reduction of the public sector. As a result of this strategy, a significant number of enterprises were pushed into bankruptcy (Mizala, 1985; Castillo, 1986). After yet another crisis in 1982 and a subsequent recovery, the situation has been marked by the coexistence of surviving firms and newly-created enterprises, helped along by a more limited process of import substitution aimed at increasing the production of consumer and capital goods.

\section{III}

\section{Successful experiences and their implications for the Latin American countries}

\section{Italy and Japan}

If the porentials of SMI in Latin America are to be assessed, then the analysis must not be confined to the regional situation alone, but must also cover the lessons that may be learned from what has occurred in other countries.

The experiences of Italy and Japan are quite exceptional and have been the most successful ones with respect to SMI in the postwar period. In the case of Japan, the approach taken has been one of industrial programming, with the entrepreneurial sector being linked to a State that takes a long-term view, and the domestic market being reserved as a basis for the expansion of manufacturing activity. In contrast, Italy represents a more spontaneous and less directed approach marked by what might be character- ized as an absence of State intervention, in which stable social balances are maintained and the economy functions as part of the European Market.

Tables 5 and 6 provide an overview of the development of SMI in these economies. A simplified outline is then presented which highlights those factors that have contributed the most to the strong growth of SMl: the socioeconomic context, the modality of development and the institutional framework.

\section{a) The socioeconomic context}

The singular course which the development of SMI has taken in Japan, coupled with the expansion of large-scale enterprise, has its origin in the Meiji Reform, undertaken in 1868, 
Table 5

ITALY: SOME INDICATORS OF THE SIGNIFICANCE OF SMI IN THE INDUSTRIAL MANUFACTURING STRUCTURE ${ }^{a}$

(Percenlages)

\begin{tabular}{|c|c|c|c|c|c|c|}
\hline \multicolumn{7}{|c|}{ Number of employees } \\
\hline & $1-9$ & $10-99$ & 101.499 & $500-999$ & & $\begin{array}{c}1000 \\
\text { and over }\end{array}$ \\
\hline \multicolumn{7}{|c|}{ Employment structure } \\
\hline 1951 & 29.6 & 23.0 & 21.1 & 9.3 & & 17.0 \\
\hline 1961 & 25.3 & 30.1 & 22.4 & 8.0 & & 14.2 \\
\hline 1971 & 20.3 & 32.7 & 23.2 & 7.7 & & 16.1 \\
\hline 1981 & 22.8 & 36.1 & 21.3 & 6.8 & & 13.0 \\
\hline \multicolumn{7}{|l|}{ Sales ${ }^{b}$} \\
\hline 1973 & 43.1 & & 50.0 & 13.4 & & 13.5 \\
\hline 1981 & 46.3 & & 41.1 & 1.4 & & 11.2 \\
\hline \multicolumn{7}{|l|}{ Exports } \\
\hline 1975 & 17.2 & & 26.0 & & 56.8 & \\
\hline 1981 & 17.7 & & 28.9 & & 53.4 & \\
\hline
\end{tabular}

Sewre: Istituto Centrale di Statistica (ISTAT) and CONFINDUSTR]A, Sestu Rapportu, Rume, 1983.

"In Italy, SMIs are defined as firms having fewer than 500 employees.

"Sales and GNP are subdivided according to the follewing categories: 20-100, 100-500, 500-1 000, 1000 or more employees.

'The employment categories used in relation to exports are: $20-100$, 100-500, 500 and over.

Table 6

JAPAN: INCIDENCE OF SMI IN THE INDUSTRIAL STRUCTURE ${ }^{a}$

(Parcentager)

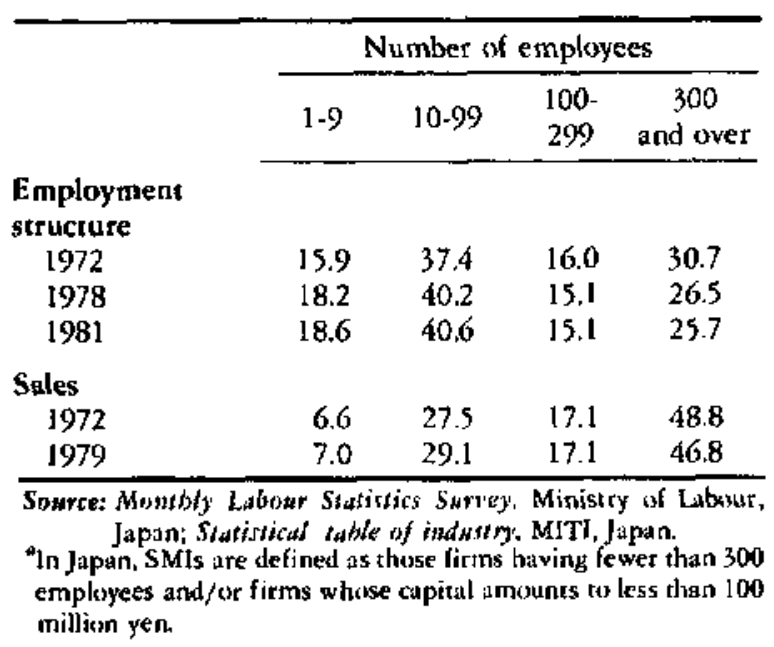

which marked the beginning of the modernization of the country and its involvement in the international system. The cultural traits peculiar to the Japanese sociery have also been a factor; these include the existence of a group-oriented culture, the traditional skillfulness in manufacturing delicate products, sound work habits and a high degree of discipline (Hosono, 1976; ECLAC, 1986; Dore, 1986; MITI, 1983 and 1986; Latin American Society, 1984 and 1985; United Nations/ESCAP, 1985; and Astorga, 1985).

Another important aspect in achieving a better understanding of this experience relates to this society's vision of the future, which has been manifested in the concerted industrial effort that has marked Japanese economic development and is its most well-known feature. ${ }^{36}$

Within this context, one of the main characteristics of the industrialization process has been the emergence and reinforcement of a new generation of entrepreneurs which has added its capabilities to those of the preceding generation. Thus, alongside the traditional sectors which resolutely embarked upon a process of assimilating Western technologies and commercial

56. The main stiges through which industrial policy has passed are: 1955-1964, priority assigned to textiles, plastics ind eiertrical items; 1965-1974, emphasis on heavy industry and television; 1975-1980, electronics, semi-conductors, numerically-controlled machine-touls and induserial robuts. 
strategies, a powerful group of national entrepreneurs has made its appearance, backed up by an institutional structure supported by a contingent of personnel devored to public service. In this way, increasingly effective tactics based on co-operation between government and industry have been used in the pursuance of economic objectives, with the Ministry of Industry and International Trade (MITI) playing a very important role in this process.

In the case of Italy, industrial development has been the outcome of the coexistence of three different models. The more industrialized regions of northern Italy have seen the consolidation of a production structure based on large enterprises which are in turn associated with a network of SMI subcontractors. In the underdeveloped areas of the south, as well as in enclaves of industrialization, a highly traditional structure of micro-enterprises has managed to survive thanks to State assistance and to their evasion of taxes. Finally, yet another model has predominated in the "Third Italy", as it is called, i.e., the central and northeastern regions, where SMI is the most important type pf productive organization in the industrial structure, and has demonstrated a great capacity for innovation and the ability to maintain a steady presence in international markets (ECLAC/UNIDO, 1986a; ECLAC, 1988). The level of development achieved by SMI, especially in the "Third Italy", is in its turn associated with various social and economic factors, including the characteristics of the agricultural sector, the social role of the family and the availability of an economic infrastructure. ${ }^{37}$

37Firstly, the extensiveness of long-standing small agricultural holdings has been a decisive factor in making independent work feasible; in time, this has led to the creation of new enterprises. Secondly, the family (which has a very strong tradition in these regions) has come to be the social struccure which backs up production activities, providing as it dues a basic source of support for the individual worker by virtue of the econonic activities it performs, and has heightened social mobility, especially between the toles of worker and entrepreneur. Finally, the expansion of ecuromic accivities and the concentration of the population in small cities has gone hand in hand with an improvement in infrastructure which has facilitated local development, thereby preventing an exodus towards large urban centres, and attracted a portion of demand from large industrial centres; this has had a fayourable effect on agricultural produstivity, tourism and other services and capital accumulation. For information concerning the case of Italy see ECL.AC/UNILO, 1986 and ECLAC, 1988.

\section{b) SMI development modalities}

In Japan, the existing links between SMIs and large enterprises were created in two ways: through the system of subcontracting by a parent company, under which SMIs produce certain previously-specified products, and through the system of subordinate affiliation, whereby small subcontractors co-operate with large companies as affiliates rather than subsidiaries. ${ }^{38}$

This dual structure, which existed in the Japanese economy until the mid-1960s, was the result of the successive predominance of two well-defined trends: a narrowing of the gap between the productivity and wages of SMIs and large enterprises; and the progressive expansion of large firms at the expense of SMIs; this last trend later began to reverse itself. 39

In the case of Italy, the distinctive feature of the way in which SMI has spread is associated with the "system-area" concept, which refers to a network of enterprises concentrated in a given territory which produce similar goods or which are vertically integrated. Within these systems each enterprise plays a specific role in the processing or production process and thus constitutes both a production unit and a user of goods or services required or supplied by other enterprises. The network as a whole behaves as one large enterprise in terms of the utilization of economies of scale, but retains the flexibility afforded by the independence of each of the component units. ${ }^{40}$

\footnotetext{
${ }_{19}$ From the vantage point of the large cumpanies, inter-firm co-uperation and complementarity has primarily involved the spheres of research, design, inspection, education and autumacion From the vantage point of SMls, however, it has chiefly concerned the manufacture of parts, assembly, the provision of facilities and equipment maintenance. It is estimared that in 1981 abuut $66 \%$ of SMls were engaging in subcontracting, particularly in the areas of transport materials (B8\%), clothing $(87 \%)$, electrical machinery $(85 \%)$, cextiles $(85 \%)$ and machinery in general $(84 \%)$.

39This turnaround was brought alouut by the enactment of legal provisions designed to prevent such practices; a delayed effect of these provisions was to encourage the growth of inter-SMI assuciative activjites. Recently, SMls have embarked upon a vigurous pruxess of modernization and automation.

${ }^{40}$ Initially, system-areas developed primarily in industries having a small volume of investment and a large number of employees in which technological innovation was not called for and the process of learning-by-doing was a significant phenumenon (fourwear, clothing, furnizure). Later, some system-a reas ceased to belong to the category of single-product enterprises as they moved towards a bruader-based type of integration; this process culminated in the $1970 \mathrm{~s}$, with the achievement by $\mathrm{SMI}$ of a
} 
The production activity to be undertaken and the type of goods and services to be produced have generally been chosen on the basis of the available technical know-how in each location, so as to take advantage of cottage-industry specializations, the low cost of manpower and the possibility of subdividing the production process among various enterprises. In addition, the existence of SMI has served to intensify the use of the pre-existing economic structure, such as houses, stables and sheds, and the utilization of prior investments (machinery and equipment) which have been discarded by other enterprises as they modernize. Finalily, in addition to the division of labour among SMIs, there has also been an integration of these companies with enterprises which supply credit, administrative and other similar services to industry. ${ }^{4 t}$

The manner in which SMI reacted to the crisis is clearly another relevant dimension of this analysis. During the 1970 s and the early 1980 s, Italian industry's response to this situation took the form of an expansionary adjustment which was buttressed by a flexibilization of the economy thorugh a greater deverticalization and decentralization of production and technology. Most new industrial facilities belong to enterprises employing fewer than 100 people, but which as a group account for a large part of the new jobs created (see table 7).

In Japan, vast sectors of SMI have recentiy been overcoming their dependence on large enterprises, and this has given rise to the restructuring of some units and the creation of others, all of which has been facilitated by the modernization and automation of such firms. Many SMIs thus appear to be taking a more independent stance in coping with the crisis as

high level of competitiveness. In parallel with this, a change has been observed in the profile of entrepreneurs, who are now second-or third-generation and rypically peussess a high level of managerial capability thanks wo their experience and to their formal training.

"Since the market of the lealian SMIs is part of the European Economic Community, the councry has perfurce adopted an intermediate position as regards liberalization, thereby permitting its small and medium-scale enterprises to exploit more easilypenetrated neighbouring markers. In Japan the contribution to exports made by SMI is substantial, but smallet than in the case of Italy.
Table 7

ITALY, JAPAN AND FEDERAL REPUBLIC OF GERMANY: CHANGES IN EMPLOYMENT IN MANUFACTURING BY FIRM SIZE, 1970-1980

\begin{tabular}{|c|c|}
\hline Country, size of firm & $\begin{array}{l}\text { Percentage } \\
\text { variation in } \\
\text { employment }\end{array}$ \\
\hline Italy & $1971-1981$ \\
\hline Up to 9 employees & 25.6 \\
\hline 10.99 & 23.1 \\
\hline $100 \cdot 400$ & 3.0 \\
\hline 500 ar more & -6.0 \\
\hline Total & 12.0 \\
\hline Japan & $1972-1981$ \\
\hline Up to 9 employees & 13.5 \\
\hline $10 \cdot 99$ & 4.9 \\
\hline $100 \cdot 299$ & -8.8 \\
\hline 300 or mote & -19.1 \\
\hline Total & -3.2 \\
\hline Federal Republic of Germany & $1970-1984$ \\
\hline $20-99$ & -33.3 \\
\hline $100-199$ & -22.6 \\
\hline $200-499$ & .20 .3 \\
\hline$\$ 00$ or more & .21 .6 \\
\hline Total & -23.9 \\
\hline
\end{tabular}

they compete with large firms in some fields of high technology, especially through what are known as "risk operations".

An indirect indicator in connection with this situation is that used in table 7 , which shows that atthough employment in manufacturing during the period 1972-1981 diminished, the proportion of such employment provided by small enterprises and the number of this type of unit increased substantially. The situation in Italy and Japan differs considerably from that existing in the Federal Republic of Germany, where employment in SMI dropped more sharply than did the average for industry as a whole.

\section{c) The institutional context}

After analysing these two cases, it may be concluded that the public institutional structure has been of greater importance in Japan. Beginning in the postwar period, the State began to show a strong determination to step up the 
development of SMI by means of policy measures in the spheres of technology, production, organization and financing. ${ }^{42}$

Notable developments have also taken place with respect to the private institutional structure in Japan. As a result of the democratization process initiated after the Second World War, the number of associations of small and mediumscale entrepreneurs increased considerably and they began to undertake activities relating to financing, the joint purchase of equipment and raw materials, training services and research and information. These associations became the focal points of the national technological information network. ${ }^{43}$

Currently, the institutional structure relating to SMI is made up of over 20 public and private agencies concerned with training, advisory services and information, integration, financing, the development of technology, product design and export promotion. These efforts are divided between the Agency for Small and Medium-Scale Enterprise, which is in charge of the design of policies and action programmes, and a group of public and private organizations which, with varying amounts of State assistance, carry out tasks in support of SMI (Astorga, 1985).

In Italy, the institutional situation is quite different. In particular, much of the growth seen in small-scale production has primarily been based on the local supply of manpower, saving capacity and entrepreneurial skills inherited from the pre-industrial era. No special public support has been provided, except in the underdeveloped areas of the south. However, a substantial volume of financial resources (a key

\footnotetext{
${ }^{42 I n} 1948$ the Agency for Smali and Medium-Scale Enterprise was created and in 1953 the SMI Stabilization Act was instituted. Then, in 1963, a series of decrees contained in the Basic Law on SMI were enacted with a view to putring a stop to the excesses commit. ted by large-scale industry in connection with subcontracting. All of these bnsic measures have been reformulated and readjusced as conditions have changed. Tu this end, there are policies concerning the modernization of equipment, the promotion of engineering technology and training, the introdaction of new administracive methods, the rectification of detrimencal situations in the field of commerce and the improvement of working conditions within such enterprises.

4In 1978 there were nearly 40000 associations of entrepreneurs, with almost $50 \%$ of SM's participaring in them. Their main tasks related to joint activities in the areas of subcontracting, the purchase of matecials, financial management and production.
}

factor for these production organizations), was made available for this process during its eariy stages.

Initiaily, co-operation among small-scale entrepreneurs in connection with the production and marketing of their products was one of the most important mechanisms used by networks of SMI, Later, greater market complexity and competition made it necessary to have a more extensive supply of information and greater management capabilities, to design common strategies and to place priority on product and service quality. The State's energetic industrial policy contributed to the accomplishment of these objectives. In recent years, attention has been focused on expanding export consortiums and providing backing for credits requested by medium-scale and small entrepreneurs.

\section{Opportunities and potentials in the region}

This analysis of successful experiences with respect to SMI provides information that can be used in assessing the potentials of SMI as regards the industrial development of the L,atin American countries. It is not a question of mechanically transferring experiences which have taken place in different societies and in different contexts, but rather of drawing lessons from these experiences which will make it possible to cast off many of the false dichotomies that muddle the discussion of this subject.

Viewing the countries of the region as a whole, three conflictive areas may be said to exist with respect to the role of SMI. The first concerns a series of divisions and gaps in the production structure which have a great deal to do with the very limited degree of socioeconomic articulation that prevails. Linked to the above, there is the more specific matter of the relations between SMI and large-scale enterprise, which was discussed in conceptual terms in the second section of this article. The third area relates to the question as to the nature of the structural effects of the crisis. This question, which has been asked so often in recent years, is closely related to the debate concerning the informal sector and its relationship to the performance of SMI. 
The available evidence indicates that there is a clear-cut difference between the economic performance of large and small enterprises, a gap between formal and informal markets and a very strong likelihood that, in the pursuance of a rapid development of technology, the distance separating traditional enterprises from modern firms is going to become increasingly greater. Furthermore, it may be concluded that out of the wide range of possible relationships between SMI and large enterprises (dependence, competitiveness and complementarity), the one most commonly found in Latin America is the last of these. This may be characterized as a "passive complementarity" in regard to both supply (subcontracting) and demand (parallel and segmented markets). Finally, it is clear that in times of prolonged economic crisis, the informal sector, micro-enterprises and some of the small enterprises whose activities are related to products or services consumed by the "poor" have the opportunity to expand, in contrast to the rest of the production structure, which stagnates (Tokman, 1987; Cornia, 1987).

Based on the above, we believe it is important to suggest at least three areas in which SMI may help to overcome the problems mentioned earlier.

Firstly SMI may play an active part in a process leading to a greater degree of socioeconomic articulation. This is because SMIs are more flexible than other enterprises, more closely linked to their markets and less autonomous in terms of co-operation and the delegation of functions. Another essential characteristic is their proximity to the source of demand, which allows them to respond swiftly to changes in the level of economic activity and to contribute to the creation of a flexible and efficient industrial system. The modality and extent of the relations between large enterprises and SMIs is far from being a trivial subject, given the vatiety of possibilities which exist, as demonstrated by the cases of Japan and Italy.

The experience of Japan shows that viewing large enterprises and SMI as if they were in opposition to one another sets up a false dichotomy, inasmuch as they may be perfectiy complementary so long as a common view of the future is shared by a social majority, a true commitment is felt to industry and a dedication to hard work is present. The case of Italy, on the other hand, teaches us that, in a situation where a large number of independent workers are present, the determining factors relate to an efficient utilization of the economic infrastructure, specialization among SMIs and vertical integration within given geographical zones.

The belief that SMIs are by nature inefficient and that they are, therefore, destined to disappear as industrial development progresses is a commonplace which must be laid to rest. Experience demonstrates that this need not be the case. It is interesting to note that the productivity ratios between SMI and large-scale enterprise in Brazil during the 1970 s did not differ substantially from those estimated for Japan. ${ }^{44}$ Moreover, even in those cases where SMI is to some extent inefficient, the possibility of using idle capacity mitigates the impact of this shortcoming.

The second area of SMI potential is that of technological progress. The experiences of Italy and Japan, with their various modalities of innovation, substantiate the fact that SMI, far from holding back technological development, can help to further it. This is because these enterprises are in a position to serve as effective channels for the dissemination of technological innovations originating at the "centre" of the system and as a production structure that fits in with the redefinitions of "economies of scale" associated with recent technological changes. Thus, in Italy there have often been cases of modern SMIs with a considerable capacity for innovation, particularly within the sphere of "system-areas", where the situation is such that many of these enterprises are able to introduce and adapt new technologies, thereby significantly contributing to the restructuring of the industrial system. In Japan, the close relationship between SMIs and large enterprises laid the groundwork for the modernization of small and

\footnotetext{
"The case of Japan may be used as a standard of refere nce. In the 1970s, the productiviry of large-scale enterprise was, on average, acound twice that of smatl-scale enterprise and 1.7 times that of medium-scale firms. It may be seen from an examination of table 4 that in Brazil the praductivity ratio of large-scale enterprise tis-d-1'ts small and medium-scale enterprise was with in the same order of magnitude (1.9\% for small-scale and $1.3 \%$ for mediumscale enterprise). In contrast, the differences in productivity for Colombia and Chile are substantialiy greater.
} 
medium-scale enterprises in terms of both the incorporation of new equipment and systems and the production of some of these items.

Finally, SMI is destined to play an active role in sociopolitical development. In this respect, there are at least three aspects which should be considered.

Firstly, because small production units are better able to adapt to cyclical fluctuations in the economy than large enterprises are, they can choose locations in relatively peripheral areas and utilize marginal segments of the labour force. In specific terms, they can thus help to lessen the concentration of the population in large urban centres and can provide incomeearning opportunities for strata which usually do not have access to them. In this sense, SMI can serve as a means of easing social tensions and of contributing to a greater degree of equity. ${ }^{45}$

The second consideration concerns the development of entrepreneurial capabilities, which have traditionally been associated at least in the literature, with the spread of small production units. This factor not only helps to improve the efficiency of the production system, but also serves to support and ensure lasting social stability. This is particularly important in the case of Latin America, in which the commitment to entrepreneurship has been consistently weak and has often been influenced by factors relating to social values.

The third aspect has to do with the political stability of democracies. This subject has not yet been analysed in sufficient depth to provide grounds for definitive conclusions. Nevertheless, the available evidence appears to indicate that the middle class is usually the social stratum that is most concerned with maintaining the stability of a liberal democracy. In some cases in

4)"An internationally competitive industrial system which is part of a sckial context within which a minimum threshold of equicy has been achieved (agrarian transformation), can help to promote equity in the country in question by virtue of a relatively broader distribution of property, in association with the creation of small and medium-sized firms; the dissemination of labour skills; faster growth of employment... The inicial expansion of the domestic market in respect of an increasingly broader range of gouds and services assuciated with growth constitures the irreplaceable basis of an industrial and techoological kearning process which is itself a prerequisite for a better type of insertion in the international ecormumy." ECLAC (1988a), p. 45. The combination of these elements has played a key role in successful cases of industrialization.
Latin America the middle class has played a crucial role in destabilizing auchoritarian régimes by non-revolutionary means. ${ }^{46}$ In this sense, it appears probable that small-scale entrepreneurs, although politically conservative, enjoy greater advantages in a democratic and participatory system. ${ }^{47}$

\section{Some policy considerations}

In order for the Latin American countries to resume a process of growth and development, their structures of production will have to undergo a through-going transformation. This statement requires that a distinction be made among at least three aspects of differing levels of specificity which influence the performance of SMI in varying ways: the types of policies that constitute the enterprises' macroeconomic frame of reference, which may be termed "factorial" policies; the form and coverage of direct assistance programmes and programmes for creating new enterprises, which may be categorized as "sectoral" policies; and, finally, the role assigned to the State. The main thrust of "factorial" policies is the maximization of the most attractive qualities of SMI. These relate to the utilization of the chief opportunities for development, such as the capacity for modernization, co-operation, specialization and subcontracting. The types of functional mechanisms involved

18 This is no doubt a highly controversial statement. Nevertheless, it is the authors' view that in a number of instances in which a society has been making a iransition towards democracy, the intervention of this segment of society, whecher appropriace or mut, has been a determining factor in the success of the process. This does not necessarily mean that the middle class is a progressive and dynamic factor nor that it is the class which fighrs the hardest in order to establish a democratic institurional scructure. However, it is the class which makes the greatest effort to mainta in such a structure unce it has been escablished.

${ }^{47} \mathrm{~A}$ system in which participation is decentralized ensures that a series of conflicts (which, in situations where $\alpha$ ) ordination is carried out at a general level, are usually amplified) will be confronted and resolved in a pragmatic fashion at the sectoral or regional level by the actors that are directly inwolved. It can be argued that, in social cerms, small and medium-scale entrepreneurs are a characteristic component of the middle class and have greater need of economic and political stability and of a low tevel of social rension than do large enterprises. In the case of ltaly, this cuncept was explicitly recognized by the first post-fascist governments; the development of a class of small-scale entrepreneurs was regarded as playing a functional role in achieving the stabilization of democracy. See ECLAC (1988). 
may be grouped in terms of cax and credit policy, technology, market access and industrial siting, training and marketing.

Within this framework, another important element is the reinforcement of the links between SMI and large economic groups which is both necessary for, and an objective of, industrial restructuring. In this connection, it is interesting to note the changes now taking place in the organization and characterization of entrepreneurs in the industrialized countries as a result of technological progress and the rapid transformation of markets: in both cases there is a tendency "to replace verrical hierarchical relations with those characterized by horizontal cooperation" (ECLAC, 1988a, p. 48). The objective is to create a flexible system of industrial production that is capable of adapting to the swift changes occurring in patterns of demand.

Insofar as "sectoral" policies are concerned, in situations where markets are undergoing a process of rearticulation and expansion, it is possible to single out, on a tentative basis, some areas of production in which SMI might be expected to figure prominently. In this respect, guidelines and instruments need to be provided that wili make it possible to prioritize and select a set of activities which would then become the main target groups for more selective assistance programmes in the fields of finance and technology. The management and transformation of demand are important matters, inasmuch as they can provide a stimulus for both routinelyused and durable consumer goods. Furthermore, the expansion of the domestic market is an inevitable consequence of a policy which promotes greater equity. SMI may benefit from policies aimed at improving product design, disseminating new technology and starting up some lines of production involving the use of high technology.

The third aspect is linked to the role of the State and its relationship to the economy. In designing strategies and policies, it is useful not only to make specific recommendations, but also to suggest ways in which the State may be more effective in promoting concerted efforts by the various agents involved. At the level of industrial strategy (the frame of reference for the development of SMI), it is assumed as a given that the system adopted should be such as to permit the coexistence of participatory planning and the market (Fajnzylber, 1983). Participatory planning would play an important role in the design of basic medium- and long-term guidelines for investment programmes in strategic sectors, the maintenance of the conditions allowing for a macroeconomic equilibrium, and the definition of sectoral promotion policies. The market, for its part, would perform an important function as a channel for the flow of information to the whole of the economic system for purposes of decentralized decision-making and the resolution of short-term tensions or maladjustments. Within this framework the market would be of less significance, however, as a basic mechanism for the allocation of resources to areas regarded as being strategic, but would continue to function as a regulator of the decentralized economy, which is the type of context that is most conducive to the operation of small enterprises.

Within this setting, the impact of policies aimed at promoting small-scale enterprise would undoubtedly extend beyond the sphere of purely economic matters and would be of importance in relation to the criteria, judgments and motivations of individuals and collectives. This is attested to by the highly significant role to be played by the formal educational system and the media in reinforcing the foundations of an efficient entrepreneurial system which would foster closer ties between the population and industry while also promoting technical progress and creativity at the local level.

\section{Bibliography}

Abluwalia, M. (1974): The scope for policy intervention. In Chenery and others: Redistribution with growth. Oxford: Oxford University Press.

Anderson, D. (1982): Small industry in developing countries. World Bank Statf Working Papers, No. 518. W/ashington, D.C.: The World Bank.
Astorga, M. (1985): Lo que Chile puede aprender del esfuerzo japonés para desarrollar sas pequeñas $y$ medianas empresasy fomentar sus exportationes. Doxument No. 5, Departamento de Administración, Universidad de Chile, Santiago, Chile. 
Bayce, R. (1984): El pequeño empresario industrial en el Uruguay y sus problemas. Caadernos de CIESU. Montevideo: Ediciones de la Banca Oriental.

Bennholdt-Thosem, V. (1979): Marginalitat in Lateinamerika. exise tbeorieknitik. Lateinamerika-Analysen und Berichte, No. 3 .

Berber, S. and J. Michael Pione (1980): Duafism und discontinutity in industrinl societies. Cambridge, Mass: Cambridge University Press.

Berry, A. and F. Thoumi (1986): Crecimiento y politicas ecunómicas en Colombia: 1970-84. Cendernos de Economia, Na. 9 Bugots: Universidad Nacional de Colombia.

Bhalla, A. and J. Dilmus (1986): Technological blending: frontiers rechnology in traditional econornic secrors. Josenal of ENo. womic Issues, vol, 20, No. 2. June.

Bromky, R. (1985): Planning for small enterprises in Third World cities. New York: Pergamun Press.

Brusco, S. (1982): The Emilian Model: productive decentralization and social integration. Cumbridge Journul of Exonomics, No. 6, London.

Canadian International Development Agency (1985): Micro and small-sale enterprises (MSE) develupment in Latin America. An overview of strategies/policies, approaches and pro. grams/projects, CIDA. Paper presented at the Regional Latin American Meeting on the Promotion of Small-Scale Enter. prise, Quico, April.

Castillo, M. (1986): E] nol de la pequeña empresa en el desarrollo económico y social: Recuento y conclusiones. Matteriales pura discusión. Centrode Estudios del Desartollo (CED). Santiago, Chile.

Chenery and others (1974): Redistribstion with grouth. Oxford: Onford University Press.

Cuhen, W., R. Levin and D. Mowery (1987): Firm size and R \& D intensity: a re-examinarion. The Josernal of Indsstrial lico. nomics, vol. 35, No. 4, June.

Cornia, G. (1987): Ajuste a nivel familiar: potencial y limituciones de las estrategias de supervivencia. In Cornia, G., R. Jolly and F. Stewart: Aitusse con rostro bumbito, Madrid:S iglo XXI de España.

Cortellese, $C$. (1986): I modelli di industrializzazione in America Latina. Potition Internazionde, No. 8-9. Rome, AugustSeptember.

Cortez, M., A. Berry and A. Ishag (1987): Success in small and medisw scule enterprises. The elidence from Colombice. Washington, D.C.: The World Bank.

De Soto. H. (19B7): El otro sendero. Le retolación informul Buenus Aires: Ed, Sudamericana.

Dore, R. (1986): Structural adjustment in Japan, 1970-1982. Geneva: ILo.

ECLAC (Economic Commission for Latin America and the Caribbean) (1985): Crisis and development; the present situation and future prospects of Latin Amertica and the Caribbean, vols. 1,2 and 3 (LC/L.332(SEM.22/3)); (LC/L.332(SEM 22/2)/Add.1) and (LC/L.332(SEM.22/3)/Add.2). Expert Meeting on Crisis and Development in Latin America and the Caribbean. Santiago, Chile, 29 April-3 May 1985.

- - (1987): Touards net forms of economic co-pperation betueen Lutin America and Jupun. Cuadernos de fa CEPAl series, No. 51 (LC/G.1354). Santiago, Chile. United Nations publication, Sales No: E.86.II.G.4.

- 1988): El proceso de defarrollo de la pequefos y mediama

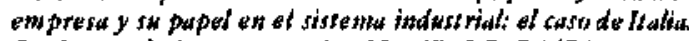
Cuadernos de la CEPAL series, No. $\$ 9$ (LC/G.1476-P). Sanriago, Chile.

_ (1988a): Restrietions on sustuined developmem in Latin Americu and the Curibbewn and the requisites for otercoming them (LC/G. 1488(SES.22/3)/Rev.1). Santiago, Chile. Twenty-second session, Rio de Janeiro, 20-27 April 1989.
ECLAC/UNIDO (1985): Empresas estatales y privadas, nacionales y extranjeras, en la estructura industrial de América Latina indastrialización y desatrallo tecnologico, Informe Na. I, Santiago, Chile: bCLAC.

- - (1986): Icalia: La importancia de la pequeña y median empresa en el desarrollo industrial. Indust rialización y desurrollo tecnologico, Informe Na. 2 (LC/G.1404) Sanciagu, Chile: ECLAC.

-(1986b): El papel de la pequeña y mediana empresa (PML) en la estructura industrial de los paises de América Latina: Una comparación con el caso de Iralia. Industriulizacion y desarmollo secnologico, Informe Nu. 3 . Santiagu, Chile: ECLAC

Escandon, J. (1981): Análisis de los factores que han determinado el desarrollo de la PME en Colombia. Coyuntura Económica, vol. XI, No. 3. Bogoti.

Estrada, F. and M. Masi (1983): El empresuriudo Latimoume ricuno: whtthos atpector. Buemus Aires: CtEDIA (Centro loterdisciplinario de Estudios sobre el Destsrollo Latimamericano).

Evans, D. (1987): The relacionship between firm growth, size, and age: estimates for 100 manufacturing industries. The Josmal of Indassrial biconomics, vol. 35, No. 4. June.

Fajnzylber, F. (1983): La indastrialización truncu de América Latina. Mexicu City: Ed. Nueva lmagen.

- - (1987): Las economís neo-industriales en el sistema cencro-periferia de los uxhenta. Coloquio "El sistema centroperiferia: presente y perspectivas". Madrid.

Fua, G. (1983): Rural induscriatization in later developed countries: the case of northeast and central Italy. Quarteriy Review, No. 147. Banca Nazionale del Lavoro. December.

FUNDACOMUN, ILDIS, CORDIPLAN (1978): La pequefa empresa en el desarrollo de America Latina. Catacas.

Garcia, A. \{1984): Indust ridixución paras el desarmllo equilativo. Munografías subre Emplea, No. 39. Santiago, Chile: PRLAIC/ISIS.

Garcia, A. and V. Tokman (1985): Acusulacion, empleo y crisis. Investigaciones sobre empleo, No. 25. Santingo, Chile: PREALC

Gómez, N. (1986): La imporancia económica y suciopolítica de ba PME en Brasil. Contribuciones, Nu. 2. Buenus Aires: Cllbil.A.

Ho, P.S. (1980): Small-scale enterprises in Korea and Taiwan. World Bank Staff Working Paper, No. 384. Washington, D.C.

Hoselicz, B.F. (1959): Small industry in underdeveloped countries. Journal of Economic History, vol. 19.

Husuno, A. (1976): Industrial development and emploxyment: the experience of $A$ sia and Latin American development strawegy. CEPAL Reviek', second sernester. Santiago, Chile. Unjted Nations publication, Sales No.; E.77.lt.G.2.

Ikonicuff, $M$. ( 1987 ): La industrialización del Tercer Mundos en ta prueba de lus grandes cambios, fil tritnestre econtomico, vol. SA(1), No. 213. Mexicu City, January-March.

(1986): La econumia subterránea y el siscema económico mundial: la experiencia de los paises de la Eurupea mediterránea. Hi irimessre econtónico, vol. $53(1)$, No. 290. Mexico City, January-March.

I1.0 (International Lalxur Office) (1972): Employment incomes und ectoulity; as strategy for increasing productive entploymen in Kunja. Geneva.

INSOTEC (Insrituwo de Investigaciones Sucikecunómicas y Tecnologicas) (1986): Pequenta y medianta indust rid ch ol Ectudor. Situación y politica de fomento 1978-1982. Quito.

Jacubsson, $S$ and $\mathrm{J}$. Sigurdson (1983): Technological trends and chellenges in electronics. Dominsmee of the indsstriadized world and responses in the Thind World. Lund, Sweden: Research Pulicy Institute.

Jacubsson, S. (1985): Technical change and industrial policy: the case of computer numerically controlled lathes in Argentina! 
Korea and Tajwan. World Developmemt, vol, 13, No.3. March.

Jaramilto, L. (1978): Difusión de tecnohogía en el Japón. Ciencics, tecnologha y desarrollo, vol. 2, No. l, Bogotá, January-March

JUNAC (Besard of the Cartagena Agreemenc) (1986): La pequeria industria en Ventezwla. Situacion y perspectitas $\mathrm{J} / \mathrm{DI} / 101$ ). Lima.

- (1987): Let pequefts industrid en el Pend (J/DI/i9). Lima.

Kaneda, H. (1980): Development of small and medium enterprises in Japan. An analytical survey. Washington, D.C.: The World Bank.

Kaplinsky, R. ( 1983 ): Firm size and technical change in a dynamic concext. The Joumal of hadust rial Exonomics, val. 32, No. 1. September.

- - (1985): Electronic-based autumation technologies and the onset of systemofacture: implications for Third World industrializarion. World Detelopment, vol. 13, No. 3. March.

Kimura, K. (1977): Japantese economy: restospects and prospecss. Aichi University, Naguya.

Kumar, M.S. (1.085): Growth, acquisition acrivity and firm size: evidence from the United Kingdom. The Journat of Inders. triat Ecomomics, val. 33, No. 3. March.

Levitsky, J. (1986): Review of World Bank lending to small enterprises, indastry Finunce Scriet, vol. 16. Washington, D.C.: the World Bank.

Lewin, A. (1985): The dialectics of dominance: petty producrion and peripheral capitalism. Planning for small enterprises in Tbird Wortd cities. R. Bromky (ed), Oxford: Pergamon Press.

Liedholm, C. and D. Mead (1987): Small scate indastries ind devel. oping countries: empiricul esidence and policy implications. MSU International Devekopment, Paper No. 9. Michigan State University.

L.itcle, I.M.D. (1987): Small manufacturing enterprises indeveloping countries. The World Bank Economic Retrek, vol l, No. 2. Washington, D.C.

Mazumdar, D. (1980): $\Lambda$ descriptive analysis of the role of smallscale enterprises in the Indian eanumy (mimeo). Washington, D.C: the World Bank.

MIT1 (1983): Informe blanco sobre la peqnena y mediand empresa. Tokyo.

- (1986): Ontline of the small and mediwm enterprises policies of the Japunese gatremmen. Agency for Strall and Medium-Scale Enuerprise.

Melke, P. (1976): Efficiency frontiers for industrial establishments of different size. Explorations in Economic Research, vol 3. No. 3. Summer.

Mizala, A. (1985): Liberalización financiera y quiebras de empresas industriales: Chile 1977-1982. Nota TÉcnica, No.67, Sanciago, Chile: CIEPLAN.

Mutioz, 0. (1986): Chile y sw industrializacion. Pasado, crisis $y$ opcioner. Santiagu, Chile: CIEPLAN.

OECD (Organization for Econamic Co-operation and Development) (1982): Innovation in small and medium size firms. Paris.

PREALC: Regional Employment Programme for Latin America and the Caribbean (1982): Planificacion del emplea. Santiago, Chile.

Pavitt, K., M. Robson and J. Townsend (1987): The size distribution of innowating firms in the UK: 1945-1983. The Jowrnal of Industrial Economics, vol. 35, No. 3. March.

Pérez, C. (1985): Micruelectronics, long wa ves anơ world strucrural change: new perspectives for developing countries. World Det'elopment, vol. 13, No. 3. March.
Secretaria de Planificación (1984): La peqpenta industria y la genetación de puestos de stabuja. Joint project of the Goveroment of Argentina/UNDP/alo.

Schmitz, H. (1980): Accumalation and employment in small.scate manufacturing: case studies from Brozil. JDS, University of Sussex.

(1982): Growth constraints on small-scale mantfacturing in developing countries: a critical review. World Derelop. ment, vol. 10, No. 6.

-- (1982a): Mansfucturing in the buckyard. Case studies on atcomulation and employment in a small.scale Brazilian industry. 1.ondun: Frames Pinter.

Schumacher, E.F. (1973): Small is beastifut, London: Blund and Briggs.

Secchi, $C$. (1985): On the role of small and medium-sized enterprises in the improvement of the production strucrure of developing countries. CI:PAJ. Retiew, No. 27 (LC/G, 1368). Santiago, Chile, December.

Sociedad Latinoumericana (1984) and (1985): Punnrama de ta indastriat y la cooperactón economitas del Japron. Takyo.

Staley, E. and R. Morse (1965): Modern Swall Industries for Developing Countries. New York: MoGraw Hill.

Steel. $W$, and Y. Takagi (1983): Small enterprises development and the employment-output trade-off. Oxford Kconomic Papers, vol. 35, No. 3, November.

Stewart, F. (1977): Technology and underdejelopmem, Lundon: MacMillan Press.

- - (1985): The fragile foundations of the neoclassical approach to development. Journal of Deselopment Studies, vol. 21, No. 2, Januiry.

Stewart, F. and P. Sireeten (1971): Conflicts berween outpuc and employment objectives in developing countries. Oxford Eto. nomic Papers. July.

Storey, J. (ed.) (1983): The small firm: an international surey. Londun: Groom Helm.

Stohr, W. (1986): Regional inmovation complexes. Papers of the Regionul Scionce Associstion, vol. 59. Philadelphia.

Tavares, M.C. and L. Courinhe (1985): La industrialización brasileța recienuc: impasse y perspectivas. Economfa de América Lutina. Mexico City: Centro de Investigación y Docencia (CU1):)/Centro de Economia Transnacional (CET).

Tukrnan, V. (1978): An exploration into the nature of informalformal relationships. World Detelopiwent, vol. 6, No. 9/10 Sepumber/October.

-_- (1987): El sector informal: quince añus después. Bl trimesire economico, vol. 54(3), No. 215. July-Sepeember.

Tuuraine, A. (1987); Actores sociales y sirtemas polticos en America Lutimu. Santiagu, Chile: PREALC.

UNIDO-StCOFI (1984): Indastria pequeña y medista en México. Mexico City, UNIDO/SECOF.

United Nations-ESCAP (Ecunumic and Social Commission for Asia and the Pacific) (1985): Smoll industry bulletin for A siz and the Pacific, No. 20. New York: United Nations publication. Sales No: E.85.II.F.22,

Vuskuvic, $P$. ( 1985 ): Debates actua les subre el desarrullo industrial de América Larina. Leconomta de América Latima. Mexico Ciry: CIDE/CET.

White, L. (1978): The evidence on appropriate factur pruportions for manufacturing in less developed councries: a survey, tico. nomic deselopment and calturst change, vol. 27, No. 1 . Octuber.

World Bank (1980): Chile: Encuesta subre las pegatefias y me. dianas industrias, Informe $\mathrm{Na} 10$. The Warld Bank/ UNIDO, February. 